\title{
Một số kết quả khảo sát về sự biến đổi của nhân vật thần từ trong thần thoại đến cổ tích thần kỳ các dân tộc ít người Việt Nam
}

Nguyễn Thị Dung*

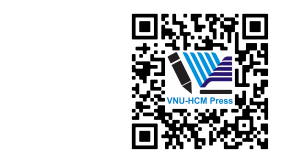

Use your smartphone to scan this QR code and download this article

Trường Đại học Lao động Xã hội, Hà Nội

Liên hệ

Nguyễn Thị Dung, Trường Đại học Lao động Xã hội, Hà Nội

Email: dungcamg@yahoo.com

Lịch sử

- Ngày nhận: 20/2/2020

- Ngày chấp nhận: 30/11/2020

- Ngày đăng: 20/12/2020

DOI : 10.32508/stdjssh.v4i4.601

\section{Check for updates}

\section{Bản quyền}

๑ Đ ĐHQG Tp.HCM. Đây là bài báo công bố mở được phát hành theo các điều khoản của the Creative Commons Attribution 4.0 International license.

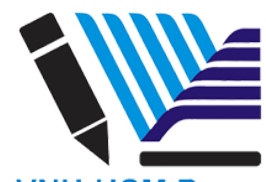

VNU-HCM Press

\begin{abstract}
TÓM TẮT
Nhân vật thần xuất hiện nhiều trong kho tàng thần thoại và truyện cổ tích của nhiều dân tộc trên thế giới. Đây là một trong những hình tượng trung tâm, thể hiện một cách tập trung nhận thức đa chiều của người xưa về tự nhiên, xã hội. Tim hiểu sự biến đổi của hệ thống nhân vật thần theo một quá trình mang tính xâu chuỗi, hệ thống từ thân thoai đến cổ tích thân kỳ các dân tộc ít người Việt Nam, chúng ta sẽ thấy được những bước phát triển vể trình độ nhận thức trong tư duy, trong đời sống tâm linh của xã hội, con người Việt Nam. Từ đó, thấy được sự phát triển trong diễn trình tư duy và diễn trình nghệ thuật bay bổng, lắng mạn của người xứa. Chúng ta còn thấy được những nét tương đông và khác biệt trong nghệ thuật xây dựng nhân vật trong thần thoại và cổ tích các dân tộc ít người.

Kết quả đặt ra của việc nghiên cứu là để nhằm tìm hiểu nguồn gốc hình thành, phương thức phản ánh thế giới, con người, quá trình biến đổi theo diễn trình tư duy và nghệ thuật của nhân vật thần từ trong thần thoại đến truyện cổ tích thần kỳ các dân tộc ít người Việt Nam thông qua các bước: 1- Mô tả và khảo sát nhân vật thần trong 181 truyện thần thoại các dân tộc ít người Việt Nam; 2 - Mô tả và khảo sát nhân vật thần trong 100 truyện cổ tích thần kỳ các dân tộc ít người Việt Nam tiêu biểu; 3 - Nhận xét, đánh giá sự biến đổi của nhân vật thần từ thần thoại đến cổ tích thần kỳ các dân tộc ít người thông qua kết quả khảo sát.

Từ khoá: thần, thần thoại, truyện cổ tích thần kỳ, biến đổi, Việt Nam
\end{abstract}

\section{MởĐẦU}

Nhân vật thần xuất hiện nhiều và là một đặc trưng trong kho tàng thân thoại và truyện cổ tích của nhiêu dân tộc trên thế giới. Thân là kiểu nhân vật thể hiện tư duy, thế giới quan của con người về tự nhiên và xã hội. Hình tượng nhân vật thân cũng rất phổ biến trong thân thoại và cổ tích thân kỳ các dân tộc ít người Việt Nam. Đây là một trong những hình tượng trung tâm, thể hiện tập trung nhận thức của người xưa về tự nhiên, xã hội, lịch sử, phản ánh tư duy trong sáng, hồn nhiên cùng những mơ ước, khát vọng của họ trong quá trình chinh phục tự nhiên và phát triển xã hội. Vì nhân vật thần trong thần thoại có ý nghĩa quan trọng như vậy nên đã có khá nhiều công trình, đề tài nghiên cứu đề cập đến. Trong số các công trình nghiên cứu đó, chúng tôi đặc biệt chú ý đến ý kiến của tác giả Mêlêtinxki trong cuốn Thi pháp của huyên thoại, người dịch Trần Nho Thìn, Song Mộc, Nxb Đại học Quốc gia Hà Nội, 2004, trang 242. Khi phân tích về nguôn gốc hình thành và đặc điểm của các vị thần, ông đã nhận định: "Các vị thần là các biểu tượng của tự nhiên... Mối liên kết giữa sự ra đời và thời niên thiếu của vị thần, của nhân vật với chất liệu ban đầu được biểu hiện qua hình tượng nước (biểu tượng điển hình cho sự hỗn mang, biểu tượng cho sự lưu chuyển khởi thủy v.v...), mặt trời, quả trứng đầu tiên (trong đó, con người và thế giới, khách thể và chủ thể không phân biệt với nhau)...”. Sự thay thế các vị thân bằng người thực thì được gán cho chế độ phong kiến. Thành ra, trong chế độ mẫu hệ, phản đề cuộc sống và cái chết lại tiếp nhận hình tượng vị thần chết đi rồi hôi sinh...Tác giả còn cho rằng những hoạt động, đặc trủng của các vị thần gắn bó chặt chẽ với những hành vi văn hóa, đặc biệt là hình tượng thần Sấm... Các vị thần và những người khổng lô đối lập nhau cả trong thời gian lẫn không gian... Trong số những huyền thoại này, cổ nhất là những truyện về những vị thân biến mất rồi quay trở lại. Những nhân vật này thực hiện các hành vi văn hoá trước, rôi không chỉ tham gia vào quá trình tạo thân hệ, sản sinh ra các vị thần mà còn nhân cách hoá các khách thể trong tự nhiên.

Khi nghiên cứu nhân vật thần trong truyện cổ tích thân kỳ, chúng tôi quan tâm tới ý kiến của V.Ia.Prốp trong công trình: Tuyển tập V.Ia.Propp, tập I, II, Nxb Văn hoá dân tộc - Tạp chí Văn hoá nghệ thuật xuất bản, Hà Nội, 2003 và 2005. Trong Hình thái học truyện cổ tích; V.Ia.Prốp đã khảo sát truyện cổ tích theo tuân tự trước sau của nó, tức là theo cấu trúc
Trích dẫn bài báo này: Dung N T. Một số kết quả khảo sát về sự biến đổi của nhân vật thần từ trong thần thoại đến cổ tích thẩn kỳ các dân tộc ít người Việt Nam. Sci. Tech. Dev. J. - Soc. Sci. Hum.; 4(4):549-566. 
tuyến tính 31 chức năng và bảy nhân vật. Khi vận dụng phương pháp nghiên cứu cấu trúc - loại hình, V.Ia.Prốp đã đưa ra khái niệm "chức năng của nhân vật hành động”. Theo ông, các nhân vật khác nhau có thể hành động khác nhau nhưng nếu những hành động này đều cùng thực hiện một chức năng giống nhau thì được xếp vào một nhóm. Chức năng của các nhân vật được xem là những đại lượng bất biến, lặp đi lặp lại. Mô hình bảy nhân vật của truyện cổ tích là: kẻ đối thủ, người cho, người trợ giúp, công chúa và vua cha, kẻ phái đi, nhân vật chính, nhân vật giả mạo. Các chức năng nhân vật làm thành yếu tố cơ bản của cấu trúc truyện cổ tích thần kỳ, tức là những yếu tố mà căn cứ vào đó, người ta xây dựng sự diễn biến của hành động.

Năm 1961, nhóm tác giả Trường Đại học Sư phạm Hà Nội trong cuốn: Giáo trình lịch sử văn học Việt Nam (Văn học dân gian) - tập 1 - Nxb Giáo dục đã đề cập đến yếu tố kỳ ảo dưới các dạng như: Bụt, tiên, thần, ma quỷ; những vật có ma lực (ngựa thân, gươm thần...) v.v...

Những nhận định của tác giả Đỗ Bình Trị trong cuốn: Những đặc điểm thi pháp của các thể loại văn học dân gian, Nxb Giáo dục, 1999, trang 14 cũng đáng được chú ý. Ông nhấn mạnh: "Lực lượng thần kỳ bao gồm: 1/ những nhân vật thần kỳ (Thần, Bụt, Tiên...), 2/ những vật có phép màu (cung tên thần, gươm thần, đàn thần, bút thân, sách ước...), 3/ sự biến hoá siêu tự nhiên (người hoá thành vật, vật hoá thành người, vật này hoá thành vật khác, người thế này hoá thành người thế khác...)".

Năm 1969, tác giả Bùi Văn Nguyên trong bài viết: "Hình tượng người anh hùng trong truyện dân gian các dân tộc thiểu số miền Bắc", Tạp chí Văn học, số 9 đã nhận định: "Người khổng lồ là trí tuệ, là anh hùng của bộ tộc đã từng khuất phục sức mạnh trên trời, dưới đất để gìn giữ và xây dựng đất nước". Ở đây, người Khổng lô đã được đề cập dưới góc độ là người anh hùng, những người khổng lồ về ý chí. Trong nghiên cứu của mình, tác giả đã làm nổi bật những đặc điểm của nhân vật thần Khổng lồ và coi đây là một trong những loại nhân vật thuộc về thần thánh. Năm 1971, Cao Huy Đỉnh với công trình nghiên cứu: Hình tượng người khổng lồ và tập thể anh hùng dựng nước và giữ nước trong truyện cổ dân gian Việt Nam là công trình đầu tiên đề cập đến người khổng lồ với tư cách là một hình tượng văn học dân gian. Tác giả đã khái quát về hình tượng người khổng lồ, lý giải nguyên nhân xuất hiện, giới thiệu một số nhân vật khổng lồ tiêu biểu như: ông Trụ Trời, ông Đào sông, Xây núi, Ải Lậc Cậc v.v... Đây là phân nghiên cứu công phu, có ý nghĩa định hướng về cách tiếp cận nhân vật như một hình tượng văn học dân gian chứa đựng nhiều giá trị nội dung và nghệ thuật.

Các tác giả Đinh Gia Khánh (chủ biên), Chu Xuân Diên, Võ Quang Nhơn trong cuốn Văn học dân gian Việt Nam, tái bản lần 8, Nxb Giáo dục, 2004 sau khi nêu ra nguồn gốc sinh ra trời đất bắt nguồn từ các vị thần ở một số dân tộc như: Thái, H’mông, Lô Lô, Bana, Chăm v.v... thì đã kết luận: “...Tên gọi các thần sáng tạo ra trời đất ở các dân tộc có khác nhau nhửng các vị thần ấy đều nằm trong một xu hướng chung; họ là một cặp vợ chông phối hợp với nhau mới sáng tạo ra đất và trời. Ở đây, rõ ràng là sự sáng tạo ra con người được các tác giả thần thoại cổ đại lấy làm khuôn mẫu để lắp ghép vào trong đời sống của thiên nhiên. Thiên nhiên đã được nhân hóa theo nhãn quan của con người là như vậy" ${ }^{1}$.

Mặc dù đã có nhiều nhà nghiên cứu như trên bàn về thần nhửng họ vẫn chưa nhìn nhận hệ thống nhân vật này một cách toàn diện dưới góc độ folklore. Vấn đề sự biến đổi của nhân vật thân từ thân thoại đến cổ tích thần kỳ các dân tộc ít người Việt Nam thì lại càng ít được các nhà nghiên cứu quan tâm đến. Những yếu tố nghệ thuật, cái tạo nên vẻ đẹp của nhân vật thân chưa được xem xét một cách thấu đáo. Hiện nay, cũng chưa có nhiều tác giả đề cập đến sự biến đổi của nhân vật thần trên hai phương diện nghệ thuật là thân thoại và cổ tích thần kỳ. Các tác giả cũng ít đề cập một cách hệ thống về các tiêu chí, cơ sở để xác định nhân vật thần trong mối quan hệ hữu cơ như: Nguôn gốc, tính chất, chức năng, hành động, tác động. Chính vì thế, chúng tôi thấy cần phải mở rộng phạm vi nghiên cứu để có cái nhìn bao quát hơn về sự biến đổi của nhân vật thân từ thần thoại đến cổ tích thần kỳ các dân tộc ít người để nhằm tìm hiểu nguôn gốc hình thành, phương thức phản ánh thế giới, con người, quá trình biến đổi theo diễn trình tư duy và nghệ thuật của loại nhân vật này trong thần thoại và truyện cổ tích thần kỳ các dân tộc ít người Việt Nam.

Thực hiện bài viết Sự biến đổi của nhân vật thân từ thân thoại đến cổ tích thần kỳ các dân tộc ít người Việt Nam, chúng tôi nhấn mạnh các nội dung sau: 1- Khảo sát 100 truyện cổ tích thân kỳ các dân tộc ít người Việt Nam có nhân vật thần.

2- Khảo sát 181 truyện có nhân vật thần thuộc thể loại thân thoại các dân tộc ít người để thấy được sự biểu hiện và biến đổi của hệ thống nhân vật này trong suốt diễn trình tư duy nghệ thuật của người xưa cho tới khi truyện cổ tích thân kỳ xuất hiện nở rộ v.v...

3- Phân tích, đánh giá, nhận xét các tiêu chí, đặc trưng của nhân vật thần thông qua một số phương diện sau: nhân vật, thế giới kỳ ảo, không gian kỳ ảo, thời gian kỳ ảo, nội dung liên quan nhân vật thần, tân số nhân 
vật thần xuất hiện, hình thức nhân vật thần xuất hiện v.v...).

Để thực hiện việc nghiên cứu Sự biến đổi của nhân vật thần từ thần thoại đến cổ tích thân kỳ các dân tộc ít người Việt Nam, chúng tôi sử dụng các phương pháp nghiên cứu sau:

- Phương pháp thống kê, khảo sát tư liệu:

+ Chúng tôi tìm đọc một số cuốn truyện thuộc thần thoại và lựa chọn những truyện có nhân vật thân tiêu biểu trong thể loại tự sự đó rồi tiến hành lựa chọn, thống kê, phân loại.

+ Chúng tôi tập trung chủ yếu vào việc tập hợp một số cuốn truyện cổ tích thân kỳ các dân tộc ít người của Việt Nam đã được xuất bản. Chúng tôi đọc tất cả và dừng lại ở những truyện có nhân vật là thần tiêu biểu. Trên cơ sở đó, chúng tôi thống kê, phân loại chúng.

- Phương pháp so sánh loại hình: Trong quá trình nghiên cứu đề tài, chúng tôi sẽ so sánh các nguôn tư liệu để thấy được đặc trưng của từng loại nhân vật thần ở mỗi thể loại (thần của thể loại thần thoại, thần trong cổ tích thân kỳ). Trên cơ sở so sánh, chúng tôi sử dụng phương pháp loại hình để khẳng định nguồn gốc, các chức năng nghệ thuật của nhân vật thần. Từ đó, chúng tôi sẽ phân tích những điểm giống và khác nhau của nhân vật thần trong mỗi thể loại; thấy được tần số xuất hiện (xuất hiện nở rộ hoặc xuất hiện ngày càng ít đi hoặc mới chớm xuất hiện) của loại hình nhân vật này trong thần thoại và cổ tích thân kỳ.

- Phương pháp hệ thống: Coi nhân vật thần là một hệ thống hoàn chỉnh, chúng tôi sử dụng phương pháp hệ thống nhằm tìm hiểu các bộ phận cấu thành của nó (nguồn gốc hình thành nhân vật, các loại nhân vật, nội dung phản ánh, phương thức phản ánh thế giới của các kiểu nhân vật).

- Phương pháp phân tích tổng hợp: Nhân vật thần sẽ được chúng tôi phân chia thành các kiểu, loại nhân vật với những chức năng khác nhau. Chúng tôi sẽ phân tích những biểu hiện cự thể của chúng. Khi phân tích tư liệu, chúng tôi chỉ chọn những dẫn chứng tiêu biểu cho nhân vật thần đó và cuối cùng là rút ra nhận xét, đánh giá tổng hợp.

\section{NộI DUNG}

\section{Khái niệm nhân vật thần và phạm vi tư liệu truyện khảo sát \\ Khái niệm nhân vật thần}

Từ trước đến nay, có khá nhiều định nghĩa, khái niệm về thân. Nhân vật thần được chúng tôi quan niệm như sau: Thân là những nhân vật được xây dựng trong trí tưởng tượng của người xưa. Thân có chức năng trợ giúp, ban tặng cho con người những phép màu...để vượt qua thử thách, thực hiện được mơ ước của mình; đồng thời, thần cũng là những nhân vật gây cản trở cho con người trong quá trình thực hiện mục đích của mình.

Trước đó, Nguyễn Đổng Chi trong công trình Lược khảo về thân thoại Việt Nam, Ban Văn Sử Địa, Hà Nội xuất bản năm 1956 khi đề cập đến thần trong thể loại thân thoại đã cho rằng: “Thân thoại là sự tích về các thân”. Thần trong thần thoại của người nguyên thủy là do quan niệm vạn vật đều có linh hồn mà xuất hiện. Thân là lực lượng siêu tự nhiên đối với con người. Hoạt động của thần thường là tự do, phóng khoáng, chất phác, vô tư.

Trong sách Lễ ký, thân được định nghĩa như sau: "Người ta chỉ chết thể xác, còn lại tinh anh, tinh thần. Nếu là người bình thường thì tinh thần đó tan biến vào không trung, nếu là người khi sống có nhiều tài ba công đức thì tinh thần đó sẽ thành thân, mãi mãi có tác động phù trợ người sống nên người sống phải thờ tế thân" ${ }^{2}$.

Tác giả Vũ Tự Lập trong cuốn Văn hóa và cư dân đồng bằng sông Cửu Long, Nxb KHXH Hà Nội, 1991 đã nhận định về thần như sau: “Thế giới tâm linh là thế giới của cái thiêng liêng, mà ở đó chỉ có cái cao cả, lương thiện và đẹp đẽ mới có thể vươn tới. Cả cộng đồng tôn thờ và cố kết nhau lại trên cơ sở của cái thiêng liêng ấy... Cái thiêng liêng ấy chính là thân”.

Hình ảnh thần trong Từ điển biểu tượng văn hóa thế giới cũng được nêu rõ: “Thần xuất hiện như một bản sao của cái tôi và còn có thể như một con người tách rời bảo vệ cho cái tôi, thần là trực giác của người đó, là tiếng nói của một lương tri siêu lý trí. Như vậy, thần cũng là người, cái bản thể tinh thần tôn tại trong mỗi con người. Người chết ra ma nhưng không phải ai cũng thành thân, phải có bản lĩnh cao cường, có công đức lớn lao hoặc chết vào giờ thiêng mới thành thần" ${ }^{3}$.

Nhân vật nào cũng có nguồn gốc hình thành. Thần trong thần thoại và cổ tích cũng vậy. Xuất phát từ tín ngưỡng nguyên thủy Vạn vật có linh hồn, con người tin rằng mọi vật xung quanh đều có linh hồn. Có thể chia ra làm bốn loại: sùng bái mọi thứ trên trời; sùng bái muôn vật dưới đất; sùng bái động vật và sùng bái con người. Con người sùng bái thế giới tự nhiên và tôn sùng các vật tổ. Từ chỗ sùng bái tín ngưỡng tô tem, con người bắt đầu hướng niềm tin của mình vào thế giới nhiên thần, tin rằng mọi vật đều chứa đựng sức mạnh huyền bí của thần linh. Đây được coi là hệ thống thần linh sơ khai, bản địa, mang lớp văn hóa xưa nhất so với các thần linh được thờ cúng về sau. Cũng từ tín ngưỡng tô tem, tín ngưỡng nhiên thần, con người lại thể hiện niềm tin, sùng bái hệ thống nhân thân. Có thể nói, quá trình con người bày tỏ và bộc lộ niềm tin từ tín ngưỡng tô tem đến tín ngưỡng 
nhiên thần rồi đến tín ngưỡng nhân thần chính là quá trình tiến hóa của sự phát triển xã hội, phát triển sản xuất và biến đổi về tư duy của con người. Đây cũng là quá trình đi từ thị tộc lên bộ tộc rồi quốc gia dân tộc. Trong quá trình này, lúc đâu vật tổ không được coi là thân. Chỉ đến khi xuất hiện người đứng đầu thị tộc, bộ lạc trở thành anh hùng, được tôn sùng là anh hùng thì lúc đó mới có thân.

Các hiện tượng tự nhiên như: mưa, gió, sấm, sét, biển cả...đã được thần thánh hóa, được thay thế bằng con người. Con người dựa vào sự kỳ vĩ, dũ dội, bí ẩn của các hiện tượng tự nhiên để tạo nên sức mạnh, uy quyền, vị thế của mình. Vì vậy, các vị thần như: thần Núi, thần Biển, thần Cây, thần Đá, thần Nước, thần Sấm, thần Mưa, thân Gió, thần Sét, thân Lửa... được hình thành. Thần chính là sản phẩm có ý thức của con người.

Do ảnh hưởng và bị chi phối sâu đậm bởi thế giới quan nguyên thủy nên ngay từ đầu, trước khi tôn giáo du nhập vào nước ta thì tín ngưỡng bản địa đã xuất hiện từ rất sớm. Tín ngưỡng này gắn liền với việc tôn thờ các lực lượng tự nhiên. Người xưa đã gắn vào đó niềm tin về sức mạnh thần bí của các hiện tượng tự nhiên và biến thành các vị thần linh thiêng, tối cao trong đời sống cộng đồng. Chính vì vậy, hình ảnh về thế giới thần linh như thần Mưa, thần Sét, thần Cây...luôn xuất hiện rất nhiều trong các truyện cổ và cũng là một hiện tượng mang tính quốc tế và khu vực.

Thần trong thần thoại mang đậm tính chất nguyên sơ, bản địa. Khi xã hội có giai cấp, khi mà con người đã trở thành trung tâm của vạn vật, hình ảnh về các vị thần cũng dần được thay đổi. Thân lúc này đã chịu sự chi phối chặt chẽ của tín ngưỡng tôn giáo. Nhân vật thần bước đầu mang những nét tình cảm, tính cách như con người nhưng chỉ được mô tả hết sức sơ lược, khái quát hóa. Đến truyện cổ tích thần kỳ, nhân vật thần cũng dần thay đổi và mang một diện mạo khác. Ngoài chức năng trợ giúp cho con người mỗi khi họ gặp khó khăn, thân linh còn gây trở ngại, đe dọa con người. Thần được biểu hiện phong phú hơn trong tình cảm, tính cách. Lúc này, thân là sự kết hợp của sự kỳ bí, oai nghiêm, có những phép màu linh thiêng, biến ảo khôn lường với những tình cảm yêu, ghét, đố ky, ích kỷ... đời thường như con người.

Nói cách khác, trước khi mâu thuẫn giữa con người và con người được đặt ra thì từ rất sớm đã xuất hiện mâu thuẫn gay gắt giữa con người với tự nhiên. Những gì con người không đủ sức giải đáp, họ đều gán cho nó một vị thần và tin vào sự tôn tại, chi phối của vị thân này. Từ đó, quan hệ giữa con người với tự nhiên và các lực lượng bao quanh nó chủ yếu được thông qua quan hệ giữa con người với các vị thần cai quản và điều phối các hiện tượng tự nhiên. Cũng từ đó, những thần thoại sớm nhất đã ra đời.

"Trong quá trình sinh sống và lao động, con người còn mong muốn chế ngự được các lực lượng tự nhiên, chiến thắng tự nhiên. Họ tự hào khi thấy được sức mạnh của chính mình. Từ đó, những người anh hùng cộng đông được nhân dân tôn thành thần thánh, ngưỡng mộ họ như là đại diện thần linh của cộng đồng, che chở và bảo vệ cộng đồng" ${ }^{4}$. Đúng như nhà nghiên cứu người Nga, $\mathrm{M}$. Gorki trong cuốn Toàn tập, quyển 30, Nxb Văn học quốc gia Matxcơva, 1951, trang 300: “Trong trí tưởng tượng của người nguyên thủy, thân không phải là cái gì trừu tượng mà là một nhân vật có thực, được trang bị bằng công cụ lao động nào đó. Thần là bậc thây ở nghề này hay nghề khác. Thần là sự khái quát nghệ thuật của những tiến bộ lao động”. Những nhân vật thần linh có nguồn gốc anh hùng bộ lạc đó đã đem vào thần thoại một luông sinh khí mới, những ước mơ bay bổng và lãng mạn, tinh thần lạc quan tràn đây trong thần thoại.

\section{Pham vi tư liẹu truyện khảo sát}

- Thần thoại: Thần chiếm số lượng và tần số xuất hiện khá lớn trong hệ thống nhân vật kỳ ảo như: Tiên, Phật, ma quỷ v.v...trong thể loại tự sự dân gian, đặc biệt là thân thoại. Trong phạm vi nghiên cứu, chúng tôi chỉ tiến hành khảo sát 181 truyện có nhân vật thần trong cuốn: Nhân vật thân kỳ các dân tộc thiểu số Việt Nam, Nxb Văn hóa Dân tộc Hà Nội, 1989 do tác giả Vũ Ngọc Khánh (chủ biên) vì muốn rằng đối tượng được khảo sát sẽ chuyên sâu, trọng tâm về cùng hệ thống, có những đặc điểm tương đông về sinh hoạt, văn hóa, ngũ̃ hệ, địa văn hóa, địa lịch sử ... của các dân tộc thiểu số.

Thân thoại của dân tộc Việt có nhân vật thần sẽ được chúng tôi đề cập đến trong một nghiên cứu khác. Như vậy, phạm vi tư liệu khảo sát của chúng tôi là 181 truyện có nhân vật thân, thuộc kho tàng thần thoại của các dân tộc ít người Việt Nam. Các dân tộc ít người này chủ yếu là Mường, Thái, H’mông, Sán Dìu, La Chí, Giáy, Cao Lan, Cơ Dong, Vân Kiêu, Rhađê, Brâu v.v... và được phân bố ở nhiều địa điểm cư trú trong cả nước.

Có thể nói, những biến đổi xã hội, lịch sử kéo theo sự biến đổi của tư duy con người. Điều đó khiến cho những thần thoại cổ xưa được lưu truyền trong dân gian đã được người đời sau tái tạo, sửa chũa, thêm bớt khiến diện mạo ban đầu của nó có phần thay đổi. Vi vậy, một số truyện đến nay rất khó tách bạch ở phương diện thể loại là thần thoại hay truyền thuyết. Nguyên do là vì đặc trưng nguyên hợp trong thân thoại các dân tộc ít người là rất đậm và hâu như còn nguyên vẹn nên 
ranh giới giữa thần thoại với các thể loại khác không hẳn là rạch ròi. Nguôn thân thoại còn lại hiện nay chủ yếu trong văn học dân gian các dân tộc ít người và cũng chưa có nhiều người quan tâm. Còn thân thoại của dân tộc Việt cũng đã được các nhà nghiên cứu quan tâm tương đối đây đủ. Đây cũng là một trong những lý do mà chúng tôi lựa chọn, tiến hành khảo sát những thần thoại có nhân vật thần của các dân tộc ít người.

- Truyện cổ tích: Truyện cổ tích là thể loại quan trọng và chiếm số lượng lớn nhất trong các thể loại tự sự dân gian. Chúng tôi lựa chọn truyện cổ tích thần kỳ để khảo sát vì đây là tiểu loại có nhiêu nhân vật thần. Sau khi đọc các tập truyện cổ tích thân kỳ các dân tộc ít người Việt Nam của nhiều tác giả, chúng tôi đã lựa chọn các tập truyện của các tác giả sau:

Nguyễn Đổng Chi với: Kho tàng truyện cổ tích Việt Nam, 5 tập, Nxb Khoa học xã hội Hà Nội, 1958-1982; Đặng Nghiêm Vạn chủ biên với: Tổng tập văn học các dân tộc ít người Việt Nam, tập 2 - truyện cổ dân gian, Nxb Đà Nẵng, 2002; Võ Quang Nhơn (1983), Văn học dân gian các dân tộc ít người ở Việt Nam, Nxb Đại học và Trung học chuyên nghiệp. Ngoài ra, để làm phong phú thêm vấn đề cân khảo sát, chúng tôi đã chọn lọc và bổ sung thêm các truyện cổ tích thân kỳ có nhân vật thần của các dân tộc ít người Việt Nam từ một số nguôn tử liệu khác.

\section{Mô tả và khảo sát nhân vật thần trong thần thoại các dân tộc ít người ở Việt Nam Mô tả nhân vật thần}

Sau khi đã giới thiệu khái quát quá trình hình thành các nhân vật thần, chúng tôi tiến hành mô tả và khảo sát 181 truyện thần thoại các dân tộc ít người có nhân vật là thần. Nhìn chung, hệ thống thân trong thần thoại các dân tộc ít người, đặc biệt là ở Nam Trung Bộ khá phong phú. Dưới quyền của Yang Paxây, còn có các vị thần: Yang Đak: thần Nước, Yang Bri: thần Rừng, Yang Bri phau: thần bản mệnh (dân tộc Brâu). Dưới quyền của thần trời Yang Adiê, còn có: Yang Hruê: thần Mặt trời, Yang Mlan: thân Mặt trăng, Yang Mta: thần Rồng, Yang Noya: thần cá sấu, Yang Cư: thần núi, Yang Eô: thần nước, Yang Lăn: thần đất (dân tộc Êđê). Ở dân tộc Giarai, có: Yang Hma: thân ruộng nương, Yang Klăn: thân sét, Yang Chứ: thần rừng, Yang Bmú: thần cây đa, Yang Blá: thần chiến tranh, Yang Pên tha: thần sinh ra dòng họ, Yang Bơ hêt Bơnghe: thần phù hộ cho trẻ em. Ở dân tộc Mạ, dưới quyền thần tối cao Yang N’Đu, còn có: Yang Bú: thần rừng...Ngoài ra, còn có hệ thống thần khác khá tiêu biểu, đa dạng, mang đậm dấu ấn vùng, miền của các dân tộc khác.
Thần thoại phản ánh mối quan hệ chủ yếu giữa con người với tự nhiên. Tư duy hồn nhiên của người xưa chỉ có thể đặt các thần tự nhiên trong sự đối sánh với thiên nhiên khổng lồ và kỳ vĩ. Vì vậy, trong thần thoại, các vị thần luôn có hình thức khổng lồ, mô phỏng sự đồ sộ của tự nhiên, vũ trụ. Ải Lậc Cậc (Thái) có thân hình khổng lồ, cao lớn. Pú Cáy (Tày) ngủ, lấy một quả núi làm gối gối đầu. Rơ Xí (Xê Đăng) thân hình to lớn như trái núi, bàn chân thần đặt đến đâu là mặt đất lõm xuống thành hồ ao. Tầm Thênh (Chăm) to lớn đến mức đầu thần ở trong nhà, thân ưỡn ra cả cánh đồng mênh mông, chân dài đến bờ biển... Tất cả các nhân vật thẩn đó đều mang một diện mạo và hình dáng dị thường.

Nhiêu thân thoại kể rằng, trước đây trời đất là một mớ hỗn độn, bùng nhùng. Sau đó, nhờ Ải Lậc Cậc (Thái), ông Chống Trời (Mường), ông Chày, bà Chày (H’mông), Ải Đăng Đen (Tày), Aê Adiê (Êđê), Tầm Thênh (Chăm) v.v...mà trời đất tách riêng ra, trời cao dần lên nhờ các thần đứng dậy đội bâu trời hoặc nhờ những cây vũ trụ như: cây si, cây đa, cây sào, cột trụ chống trời cao lên. Vũ trụ được kiến tạo nhờ những người khổng lô đó. Thần Trụ Trời (Việt) dùng đôi tay khổng lô đào đất, đắp cột chống trời, khi trời đất xa nhau, thần mới phá cột đi. Đất đá văng ra thành đôi núi, nơi đào đất thành biển. Ải Lậc Cậc (Thái) đồ xôi ở Mường Thanh, ba ông đầu rau là ba quả núi nay vẫn chụm đầu ở đó v.v...

\section{Khảo sát nhân vật thần}

Chúng tôi tiến hành khảo sát nhân vật thần theo các tiêu chí sau: số lượng thần, tần số xuất hiện của thần, không - thời gian nhân vật thần xuất hiện, nội dung truyện, tác động truyện... 


\begin{tabular}{|c|c|c|c|c|c|}
\hline Stt & Thần & Số lượng & $\begin{array}{l}\text { Tần số xuất } \\
\text { hiện (lần) }\end{array}$ & Số lượt truyện & $\begin{array}{l}\text { Số lượt dân } \\
\text { tộc }\end{array}$ \\
\hline 1 & Thần & $142(26,44 \%)$ & $297(20,26 \%)$ & $60(16,75 \%)$ & $60(16,75 \%)$ \\
\hline 2 & Thần Trời & $129(24,02 \%)$ & $289(19,71 \%)$ & $79(22,06 \%)$ & $79(22,06 \%)$ \\
\hline 3 & Khổng lồ & $94(17,5 \%)$ & $298(20,32 \%)$ & $52(14,52 \%)$ & $52(14,52 \%)$ \\
\hline 4 & Thần Đất & $16(2,98 \%)$ & $49(3,34 \%)$ & $12(3,35 \%)$ & $12(3,35 \%)$ \\
\hline 5 & Thần Lúa & $11(2,04 \%)$ & $39(2,7 \%)$ & $11(3,07 \%)$ & $11(3,07 \%)$ \\
\hline 6 & Thân Nước & $11(2,04 \%)$ & $43(2,97 \%)$ & $11(3,07 \%)$ & $11(3,07 \%)$ \\
\hline 7 & Thần Sét & $9(1,67 \%)$ & $36(2,49 \%)$ & $9(2,51 \%)$ & $9(2,51 \%)$ \\
\hline 8 & Thần Lửa & $8(1,49 \%)$ & $25(1,72 \%)$ & $8(2,23 \%)$ & $8(2,23 \%)$ \\
\hline 9 & Thân Mặt trời & $8(1,49 \%)$ & $35(2,42 \%)$ & $8(2,23 \%)$ & $8(2,23 \%)$ \\
\hline 10 & Thân Rượu & $7(1,30 \%)$ & $8(0,55 \%)$ & $3(0,83 \%)$ & $3(0,83 \%)$ \\
\hline 11 & Thần nông nghiệp & $6(1,12 \%)$ & $8(0,55 \%)$ & $6(1,67 \%)$ & $6(1,67 \%)$ \\
\hline 12 & Thần Cây & $5(0,93 \%)$ & $16(1,10 \%)$ & $5(1,39 \%)$ & $5(1,39 \%)$ \\
\hline 13 & Thần Biển & $5(0,93 \%)$ & $18(1,24 \%)$ & $5(1,39 \%)$ & $5(1,39 \%)$ \\
\hline 14 & Thần Nỏ & $4(0,74 \%)$ & $5(0,34 \%)$ & $4(1,11 \%)$ & $4(1,11 \%)$ \\
\hline 15 & Thần Thuông luồng & $4(0,74 \%)$ & $18(1,22 \%)$ & $4(1,11 \%)$ & $4(1,11 \%)$ \\
\hline 16 & Thần Gió & $4(0,74 \%)$ & $14(0,97 \%)$ & $4(1,11 \%)$ & $4(1,11 \%)$ \\
\hline 17 & Thần Núi & $4(0,74 \%)$ & $16(1,10 \%)$ & $4(1,11 \%)$ & $4(1,11 \%)$ \\
\hline 18 & Thân Chớp & $4(0,74 \%)$ & $8(0,55 \%)$ & $4(1,11 \%)$ & $4(1,11 \%)$ \\
\hline 19 & Thân Sinh tử & $4(0,74 \%)$ & $4(0,27 \%)$ & $4(1,11 \%)$ & $4(1,11 \%)$ \\
\hline 20 & Thần Sấm & $4(0,74 \%)$ & $18(1,24 \%)$ & $4(1,11 \%)$ & $4(1,11 \%)$ \\
\hline 21 & Thần Sinh đẻ & $4(0,74 \%)$ & $28(1,93 \%)$ & $4(1,11 \%)$ & $4(1,11 \%)$ \\
\hline 22 & Thần Cầu vồng & $3(0,56 \%)$ & $12(0,82 \%)$ & $3(0,83 \%)$ & $3(0,83 \%)$ \\
\hline 23 & Thân Rừng & $3(0,56 \%)$ & $14(0,97 \%)$ & $3(0,83 \%)$ & $3(0,83 \%)$ \\
\hline 24 & $\begin{array}{l}\text { Thần Mẹ Yang Po Inư } \\
\text { Nưgar }\end{array}$ & $3(0,56 \%)$ & $24(1,66 \%)$ & $3(0,83 \%)$ & $3(0,83 \%)$ \\
\hline 25 & $\begin{array}{l}\text { Thần sáng tạo và hủy } \\
\text { diệt Shiva }\end{array}$ & $3(0,56 \%)$ & $12(0,82 \%)$ & $3(0,83 \%)$ & $3(0,83 \%)$ \\
\hline 26 & Thần Mưa & $3(0,56 \%)$ & $5(0,34 \%)$ & $2(0,55 \%)$ & $2(0,55 \%)$ \\
\hline 27 & Thần linh & $2(0,37 \%)$ & $2(0,13 \%)$ & $2(0,55 \%)$ & $2(0,55 \%)$ \\
\hline 28 & Thân làng & $2(0,37 \%)$ & $9(0,62 \%)$ & $2(0,55 \%)$ & $2(0,55 \%)$ \\
\hline 29 & Thần Rắn & $2(0,37 \%)$ & $10(0,7 \%)$ & $2(0,55 \%)$ & $2(0,55 \%)$ \\
\hline 30 & Thần buôn làng & $2(0,37 \%)$ & $6(0,41 \%)$ & $2(0,55 \%)$ & $2(0,55 \%)$ \\
\hline 31 & Thần mặt trăng & $2(0,37 \%)$ & $6(0,41 \%)$ & $2(0,55 \%)$ & $2(0,55 \%)$ \\
\hline 32 & Thần tạo hóa Brahma & $2(0,37 \%)$ & $13(0,9 \%)$ & $2(0,55 \%)$ & $2(0,55 \%)$ \\
\hline 33 & Thân bảo tôn Vishnu & $2(0,37 \%)$ & $5(0,34 \%)$ & $2(0,55 \%)$ & $2(0,55 \%)$ \\
\hline 34 & Thần Rẫy & $1(0,19 \%)$ & $1(0,07 \%)$ & $1(0,28 \%)$ & $1(0,28 \%)$ \\
\hline 35 & Thân Chim & $1(0,19 \%)$ & $1(0,07 \%)$ & $1(0,28 \%)$ & $1(0,28 \%)$ \\
\hline 36 & Thần Cóc & $1(0,19 \%)$ & $9(0,62 \%)$ & $1(0,28 \%)$ & $1(0,28 \%)$ \\
\hline 37 & Thân Nông & $1(0,19 \%)$ & $5(0,34 \%)$ & $1(0,28 \%)$ & $1(0,28 \%)$ \\
\hline 38 & Thần Mối & $1(0,19 \%)$ & $2(0,12 \%)$ & $1(0,28 \%)$ & $1(0,28 \%)$ \\
\hline 39 & Thần bản & $1(0,19 \%)$ & $1(0,07 \%)$ & $1(0,28 \%)$ & $1(0,28 \%)$ \\
\hline 40 & Thần Ác & $1(0,19 \%)$ & $6(0,41 \%)$ & $1(0,28 \%)$ & $1(0,28 \%)$ \\
\hline 41 & Thần nhân & $1(0,19 \%)$ & $6(0,41 \%)$ & $1(0,28 \%)$ & $1(0,28 \%)$ \\
\hline 42 & Thân Mây & $1(0,19 \%)$ & $1(0,07 \%)$ & $1(0,28 \%)$ & $1(0,28 \%)$ \\
\hline 43 & Thần Bò Nandin & $1(0,19 \%)$ & $1(0,07 \%)$ & $1(0,28 \%)$ & $1(0,28 \%)$ \\
\hline 44 & Thần Thuốc & $1(0,19 \%)$ & $1(0,07 \%)$ & $1(0,28 \%)$ & $1(0,28 \%)$ \\
\hline 45 & Thần Bầu & $1(0,19 \%)$ & $1(0,07 \%)$ & $1(0,28 \%)$ & $1(0,28 \%)$ \\
\hline 46 & Thần Bếp & $1(0,19 \%)$ & $12(0,82 \%)$ & $1(0,28 \%)$ & $1(0,28 \%)$ \\
\hline
\end{tabular}




\begin{tabular}{|c|c|c|c|c|c|}
\hline \multicolumn{6}{|c|}{ Table 1 continued } \\
\hline 47 & Thần nhà & $1(0,19 \%)$ & $6(0,41 \%)$ & $1(0,28 \%)$ & $1(0,28 \%)$ \\
\hline 48 & Thần giữ hồ & $1(0,19 \%)$ & $1(0,07 \%)$ & $1(0,28 \%)$ & $1(0,28 \%)$ \\
\hline 49 & $\begin{array}{l}\text { Thân Lakshmi (giàu có, } \\
\text { thịnh vượng) }\end{array}$ & $1(0,19 \%)$ & $1(0,07 \%)$ & $1(0,28 \%)$ & $1(0,28 \%)$ \\
\hline 50 & Thần tổ tiên & $1(0,19 \%)$ & $3(0,20 \%)$ & $1(0,28 \%)$ & $1(0,28 \%)$ \\
\hline 51 & Thân ánh sáng & $1(0,19 \%)$ & $1(0,07 \%)$ & $1(0,28 \%)$ & $1(0,28 \%)$ \\
\hline 52 & $\begin{array}{l}\text { Thần làm công trình } \\
\text { thủy lợi }\end{array}$ & $1(0,19 \%)$ & $1(0,07 \%)$ & $1(0,28 \%)$ & $1(0,28 \%)$ \\
\hline 53 & Thân Đá & $1(0,19 \%)$ & $4(0,27 \%)$ & $1(0,28 \%)$ & $1(0,28 \%)$ \\
\hline 54 & Thân Chó & $1(0,19 \%)$ & $7(0,48 \%)$ & $1(0,28 \%)$ & $1(0,28 \%)$ \\
\hline 55 & Thân Lợn & $1(0,19 \%)$ & $1(0,07 \%)$ & $1(0,28 \%)$ & $1(0,28 \%)$ \\
\hline 56 & Thân Trâu & $1(0,19 \%)$ & $1(0,07 \%)$ & $1(0,28 \%)$ & $1(0,28 \%)$ \\
\hline 57 & Thân âm nhạc Sarasvati & $1(0,19 \%)$ & $1(0,07 \%)$ & $1(0,28 \%)$ & $1(0,28 \%)$ \\
\hline \multirow[t]{2}{*}{58} & Thân Ngỗng trời Hamsa & $1(0,19 \%)$ & $1(0,07 \%)$ & $1(0,28 \%)$ & $1(0,28 \%)$ \\
\hline & Tổng (58 loại) & 537 100\%) & $1.466(100 \%)$ & $358(100 \%)$ & $358(100 \%)$ \\
\hline
\end{tabular}


- Về số lượng và tần số xuất hiện của nhân vật thần: Chúng tôi khảo sát 181 truyện và phân loại được 58 loại nhân vật thần (Bảng 1). Từ 58 loại nhân vật đó, chúng tôi thống kê được số lượng nhân vật thần là 537 (một loại nhân vật có thể có số lượng là 2 hoặc 3 nhân vật. Nếu cộng lại sẽ ra tổng là 537 nhân vật). Trong số 537 nhân vật thần này, thần (nói chung) là loại nhân vật chiếm tỷ lệ cao nhất: 142/537 nhân vật, chiếm 26,44\%. Đây là loại nhân vật có tân số xuất hiện lớn nhất với: 297/1466 lần, chiếm 20,26\%. Chiếm tỷ lệ thấp nhất thuộc về thần Chó, thân Lợn, thân Đá, thân Trâu v.v...Các nhân vật này đều có số lượng là 01 , chiếm $0,19 \%$ và có tần số xuất hiện là 01 lần, chiếm $0,07 \%$.

- Về giới tính nhân vật thần: Trong số 537 nhân vật thân, có 373 nhân vật là nam giới, chiếm 69,45\%; 164 nhân vật là nữ giới, chiếm $30,55 \%$. Nam giới xuất hiện nhiều trong truyện một phân là phụ thuộc vào quan niệm thẩm mỹ của người xưa, một phân là căn cứ vào vai trò, chức năng của người đàn ông trong đời sống sinh hoạt, kinh tế - xã hội. Theo quan niệm dân gian, ngay từ xa xưa, nam giới đã đóng vai trò quan trọng trong việc kiến tạo cuộc sống, gánh vác những công việc quan trọng trong gia đình và xã hội. Trong công cuộc khai phá và chinh phục tự nhiên, đòi hỏi con người phải có sức mạnh về thể chất, tinh thân, trí tuệ... để thực hiện những công việc nặng nhọc nhằm "dời non lấp bề, chiến thắng thú dũ̃, đánh thắng kẻ thù v.v...Nam giới là hình tượng phù hợp để thể hiện quan niệm thẩm mỹ của người xưa và thực tế đã chứng minh là đúng như vậy.

Trong thân thoại các dân tộc ít người, chúng ta hay bắt gặp hình tượng thân Trời, còn có tên khác là Giàng, Then...Đây được coi là vị thân (nam giới) tối cao, chi phối tất cả mọi thứ xung quanh. Ngẩng đầu lên là bâu trời trên cao, đây bí hiểm, con người khao khát muốn tìm hiểu và đã thân linh hóa để suy tôn lên thành chúa của vũ trụ. Thần Trời đứng đầu các thần điêu khiển tạo hóa ở ngoại cảnh. Thần vạch đường cho sông chảy, đắp đất cho núi cao. Thần điều hòa bốn mùa.

Chúng ta cũng thường bắt gặp hình ảnh các vị thần như thần Đất, thần Mưa, thần Núi, thần Sấm v.v... Hình ảnh thần Đất đâu tiên thuộc về các nũ̃ thần, sau đó mới chuyển hóa sang là nam thần. Điều này gắn liền với quá trình biến chuyển lao động từ săn bắn, sang chăn nuôi và trông trọt với sự tan rã của chế độ mẫu quyền và manh nha của chế độ phụ quyền. Loài người sau một quá trình chinh phục thiên nhiên rất vất vả đã đưa sản xuất và đời sống đến một trình độ cao, trên cơ sở canh tác nông nghiệp. Hình tượng thân Đất tiêu biểu cho nguyện vọng và ý chí con người bắt thiên nhiên phải khuất phục người và nuôi sống người. Mặt khác, qua câu chuyện, ta cũng thấy địa vị của người đàn bà đã bắt đầu không được coi trọng. Người đàn ông có sức lực và khả năng đảm nhận vai trò mới trong nền sản xuất mới ngày càng được đề cao. Trong thần thoại xưa nhất về thần Đất, ta chỉ thấy bà mẹ Đất là nguồn gốc của mọi sinh vật và của cải nhưng ở đây thần Đất phải sản xuất theo lệnh của cha và chông, phải mang tên chông.

- Về thế giới kỳ ảo mà nhân vật thần xuất hiện:

Như chúng tôi đã trình bày ở trên, tổng số truyện mà chúng tôi khảo sát là 181 truyện nhưng thực tế lại có 215 lượt truyện có thế giới kỳ ảo. Tại sao lại có hiện tượng này? Trong quá trình khảo sát, chúng tôi nhận thấy là: Cùng trong một truyện, có những nhân vật thân chỉ xuất hiện trong một thế giới kỳ ảo duy nhất. Tuy nhiên, cũng có nhiều truyện, nhiều nhân vật thần xuất hiện trong nhiều thế giới kỳ ảo khác nhau hoặc một nhân vật thần xuất hiện trong nhiêu thế giới kỳ ảo khác nhau. Điều này tạo nên số lượt truyện có thế giới kỳ ảo tăng lên là 215, mặc dù số lượng truyện thực tế là 181. Ngoài thế giới Trần gian, Thiên phủ, Âm phủ, thân còn xuất hiện cùng lúc trong các thế giới như: Trân gian - Âm phủ - Thiên phủ - Thủy phủ. Chúng tôi tạm gọi những thế giới kỳ ảo mà nhân vật thần lần lượt xuất hiện đồng thời trong truyện là thế giới kỳ ảo hỗn hợp.

Trong các thế giới kỳ ảo mà thần xuất hiện, thế giới kỳ ảo hỗn hợp mà thần xuất hiện nhiều nhất là: 127/215 truyện, chiếm 59,06\%. Theo quan niệm của người xưa, lúc này vũ trụ hỗn mang, ranh giới giữa các cõi chưa hề có sự chia tách, riêng biệt cho nên việc các nhân vật thần xuất hiện với số lượng lớn cũng là điêu có thể hiểu được. Tiếp đó là thế giới trần gian với: 49/215 truyện, chiếm 22,8\%. Chiếm tỷ lệ thấp nhất là thế giới thiên phủ với: 39/215 truyện, chiếm 18,14\%. Điều này phụ thuộc vào quan niệm "ba tâng, bốn thế giới” của người xưa. Các nhân vật thân không ở yên một vị trí mà thường xuyên đi mây về gió để thực hiện chức năng phù trợ, giúp đỡ hoặc cản trở con người. Dù thế giới thiên phủ, thủy phủ là thế giới mơ ước của con người nhửng trần gian vẫn là nơi mà họ thấy gắn bó, thân thuộc và trong quan niệm của người xưa, các vị thần dù có những tính năng, phép màu kỳ diệu nhưng cũng có cuộc sống như con người.

- Về không gian kỳ ảo mà nhân vật thần xuất hiện: Trong số 181 truyện, có 129/181 truyện, chiếm $71,27 \%$ có không gian kỳ ảo, rộng lớn, không xác định; 52/181 truyện, chiếm 28,73\% có không gian kỳ ảo cụ thể, xác định. Việc nhân vật thân xuất hiện nhiều ở những không gian rộng lớn, mông lung là cũng tương ứng với việc thần xuất hiện trong thế giới kỳ ảo rộng lớn. Do việc thường xuyên ở những cõi giới khác nhau, di chuyển từ thiên phủ, tới trần gian, xuống thủy cung và âm phủ nên hâu như không có ranh giới 
giữa các thế giới kỳ ảo. Không gian kỳ ảo vì thế cũng gắn liền với thế giới kỳ ảo và có mối liên hệ mật thiết với nhau. Những không gian cụ thể, xác định thường hẹp như: bến nước, cây đa, làng, xóm...và liên quan đến sự xuất hiện của các vị thân vốn gắn bó, "cư trú" lâu đời như: thần cây đa, thần Miếu...

- Về thời gian kỳ ảo mà nhân vật thần xuất hiện: Trong số 181 truyện, có 90/181 truyện, chiếm 49,72\% nhân vật thần xuất hiện trong nhiều ngày; 86/181 truyện, chiếm $47,51 \%$ nhân vật thần xuất hiện trong nhiêu ngày đêm; 3/181 truyện, chiếm 1,66\% nhân vật thần xuất hiện trong nhiêu năm tháng; $2 / 181$ truyện, chiếm $1,10 \%$ nhân vật thần xuất hiện trong hàng vạn năm. Nhân vật thần xuất hiện trong nhiều ngày ở trong truyện có liên quan đến việc nhân vật chính đó phải thực hiện nhiều nhiệm vụ, nhiều chức năng, gặp hết thử thách này đến thử thách khác mà chưa thực hiện xong. Nhân vật thần xuất hiện trong nhiều ngày, nhiều đêm, gắn liền với nhiều lần trợ giúp, thực hiện các nhiệm vụ có tầm vóc vũ trụ làm cho mạch truyện giãn dài ra, hấp dẫn hơn. Đây là những truyện xuất hiện muộn hơn so với thần thoại sơ khai vốn xuất hiện từ trước đó.

- Về nội dung và tác động của truyện có nhân vật thần: Nhân vật thần xuất hiện trong truyện thần thoại chủ yếu là để thể hiện ước mơ chiến thắng tự nhiên, câu ước mưa thuận gió hòa, cuộc sống no đủ, công bằng, chiến thắng kẻ thù v.v...Trong số 181 truyện mà chúng tôi khảo sát, có 69/181 truyện, chiếm 38,12\% (đây là tỷ lệ lớn nhất) có nội dung giải thích sự hình thành các hiện tượng tự nhiên - xã hội; tiếp đó là các truyện có nội dung thể hiện ước mơ cuộc sống no đủ, công bằng: 29/181 truyện, chiếm $16,02 \%$; tiếp đó là nội dung chiến thắng tự nhiên: 22/181 truyện, chiếm $12,15 \%$; sau đó là các truyện có nội dung thể hiện ước mơ chiến thắng kẻ thù: $16 / 181$ truyện, chiếm $8,83 \%$; câuu ước mưa thuận gió hòa: 12/181 truyện, chiếm 6,62\%; ước mơ hôn nhân - hạnh phúc: 9/181 truyện, chiếm 4,97\%; nội dung cảnh tỉnh con người: 8/181 truyện, chiếm $4,41 \%$; ước mơ vượt qua thử thách: 6/181 truyện, chiếm 3,31\%; sở hữu phương tiện thần kỳ: $6 / 181$ truyện, chiếm $3,31 \%$; khát vọng thay đổi địa vị: $5 / 181$ truyện, chiếm 2,76\%; thấp nhất là truyện có nội dung gây hại: $1 / 181$ truyện, chiếm $0,55 \%$...Các tỷ lệ khảo sát trên đây cũng hoàn toàn phù hợp với những đặc điểm về nội dung thẩn thoại sớm nhất nói chung, đó là nội dung giải thích sự hình thành các hiện tượng tự nhiên - xã hội, mong muốn và khát vọng chinh phục, chiến thắng tự nhiên. Con người chỉ vì một niềm hy vọng duy nhất là: sản xuất ngày một dễ dàng hơn, của cải, súc vật và ngũ cốc ngày càng nhiêuu hơn, đời sống yên lành hơn, không có kẻ thù hung ác từ ngoài bộ lạc đến quấy nhiễu nữa. Các nội dung khác xuất hiện muộn hơn và có sự ảnh hưởng với các thể loại tự sự dân gian khác bởi vì đặc trưng nguyên hợp trong thần thoại các dân tộc ít người là khá đậm và nguyên vẹn.

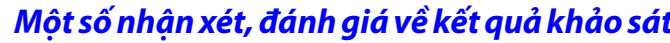 nhân vật thần trong thần thoại các dân tộc ít người Việt Nam}

Sau khi tiến hành khảo sát các nhân vật thần theo các tiêu chí trên, chúng tôi đưa ra một số nhận xét, đánh giá như sau:

- Nhân vật thần xuất hiện chủ yếu trong 181 truyện là các vị thần nói chung, thần Trời, thần Khổng lồ, thần Đất, thần Mưa, thân Lúa, thần Nước, thân Sét, thân Mặt trời... Các vị thần này có mối liên hệ mật thiết với đời sống sản xuất nông nghiệp của con người thời cổ. Đây đều là các lực lượng siêu nhiên hùng vĩ, bí ẩn, mông lung, choáng ngợp. Các nhân vật này phân lớn có chức năng xây dựng và kiến tạo vũ trụ.

- Bên cạnh những vị thần gắn liền với các hiện tượng tự nhiên, còn có những nhân vật gắn liền với đời sống xã hội, sinh hoạt, với các tập quán, phong tục của con người như: thân Bếp, thần nhà, thân bản, thần làng, thân Sinh tử, thần Sinh đẻ, thân tổ tiên...Các thân thoại ít nhiều pha màu sắc linh thiêng của tín ngưỡng khi nói về việc hình thành khu vực cai quản và ảnh hưởng của các thần.

\section{Mô tả và khảo sát nhân vật thần trong một số truyện cổ tích thần kỳ các dân tộc ít người Việt Nam}

\section{Mô tả nhân vật thần}

Chúng tôi đã thống kê được 100 truyện cổ tích thần kỳ các dân tộc ít người Việt Nam có nhân vật thân. Nhóm các vị thần bao gồm: các thần nói chung, thân Nước, thần Núi, thần Lúa, thần Sét, thân Đất, thần Sông, sơn thần, thần Cây, thần Đá, thân Miếu, thần Thiện, thần Ác, thần Hang, thần ngôi đền, thần Suối, thần Gió, thần Mối, thần Rừng, thần Sóng, thần Khổng lồ v.v... Thần ở thế giới trên cao với những uy quyền tuyệt đối vẫn là những nhân vật mà con người ngưỡng mộ, sùng kính. Mặc dù thần vừa cứu giúp con người, vừa đe doạ, cản trở con người thực hiện mơ ước của mình nhưng họ vẫn hướng niềm tin, niềm hy vọng của mình đến hệ thống thần này. Con người vẫn luôn câu mong các vị thần hiểu được ước muốn của họ; giúp họ được thay đổi vận mệnh cuộc đời.

Trong quá trình khảo sát 100 truyện có nhân vật thần, chúng tôi nhận thấy: Có những truyện vừa có thần, vừa có thần Khổng lồ...Có những truyện lại có sự xuất hiện từ ba đến bốn loại nhân vật như: thân Cây, thân Núi, thân Lủa, thân Bếp v.v...Như vậy, sẽ có nhiều 
nhân vật xuất hiện trong một truyện. Truyện này sẽ chứa nhiều nhóm nhân vật khác nhau. Và cứ mỗi loại nhân vật lại tương ứng với một lần xuất hiện trong một truyện. Có bao nhiêu loại nhân vật thì sẽ có bấy nhiêu truyện tương ứng với các nhân vật đó. Khi khảo sát, chúng tôi sẽ căn cứ vào số nhân vật thần xuất hiện trong truyện để tổng hợp số liệu truyện cụ thể. Chúng tôi gọi đó là các lượt truyện vì các truyện này có sự xuất hiện lặp đi lặp lại cùng với các nhóm nhân vật thần khác nhau.

\section{Khảo sát nhân vật thần}

Tương tự như vậy, trong những truyện mà chúng tôi khảo sát, có nhiêu truyện do có sự xuất hiện chông chéo của nhiều nhân vật thần khác nhau, thậm chí là có sự lặp lại nhiêu lần ở cùng một truyện hay nhiêu truyện nên đã tạo ra nhiều lượt truyện khác nhau. Số lượt truyện có nhân vật thân sẽ xuất hiện nhiều hơn 100 truyện chính thức được khảo sát. 


\begin{tabular}{|c|c|c|c|c|c|}
\hline Stt & Thần & Số lượng & $\begin{array}{l}\text { Tần số } \\
\text { xuất hiện }\end{array}$ & Số lượt truyện & $\begin{array}{l}\text { Số lượt } \\
\text { dân tộc }\end{array}$ \\
\hline 1 & Thân & $\begin{array}{l}140 \\
(57,61 \%)\end{array}$ & $166(49,25 \%)$ & $33(25,38 \%)$ & $33(25,38 \%)$ \\
\hline 2 & Thần Nước & $11(4,52 \%)$ & $38(11,27 \%)$ & $8(6,15 \%)$ & $8(6,15 \%)$ \\
\hline 3 & Thần Núi & $9(3,70 \%)$ & $13(3,86 \%)$ & $9(6,92 \%)$ & $9(6,92 \%)$ \\
\hline 4 & Thần Lúa & $8(3,29 \%)$ & $3(0,89 \%)$ & $1(0,77 \%)$ & $1(0,77 \%)$ \\
\hline 5 & Thần Sét & $7(2,88 \%)$ & $8(2,37 \%)$ & $4(3,07 \%)$ & $4(3,07 \%)$ \\
\hline 6 & Thần Đất & $5(2,05 \%)$ & $11(3,26 \%)$ & $4(3,07 \%)$ & $4(3,07 \%)$ \\
\hline 7 & Khổng lô & $4(1,64 \%)$ & $12(3,56 \%)$ & $4(3,07 \%)$ & $4(3,07 \%)$ \\
\hline 8 & Thần linh & $4(1,64 \%)$ & $5(1,48 \%)$ & $4(3,07 \%)$ & $4(3,07 \%)$ \\
\hline 9 & Nũ thần Đá & $4(1,64 \%)$ & $4(1,19 \%)$ & $2(1,53 \%)$ & $2(1,53 \%)$ \\
\hline 10 & Thần nhân & $4(1,64 \%)$ & $5(1,48 \%)$ & $3(2,3 \%)$ & $3(2,3 \%)$ \\
\hline 11 & Thân Biển & $3(1,23 \%)$ & $9(2,67 \%)$ & $2(1,53 \%)$ & $2(1,53 \%)$ \\
\hline 12 & Thần Rông & $3(1,23 \%)$ & $5(1,48 \%)$ & $3(2,3 \%)$ & $3(2,3 \%)$ \\
\hline 13 & Thần Sông & $3(1,23 \%)$ & $2(0,59 \%)$ & $1(0,77 \%)$ & $1(0,77 \%)$ \\
\hline 14 & Sơn thần & $3(1,23 \%)$ & $1(0,3 \%)$ & $1(0,77 \%)$ & $1(0,77 \%)$ \\
\hline 15 & Thần Bếp & $3(1,23 \%)$ & $1(0,3 \%)$ & $1(0,77 \%)$ & $1(0,77 \%)$ \\
\hline 16 & Thần Cây & $2(0,82 \%)$ & $11(3,26 \%)$ & $2(1,53 \%)$ & $2(1,53 \%)$ \\
\hline 17 & Thần Miếu & $2(0,82 \%)$ & $8(2,37 \%)$ & $2(1,53 \%)$ & $2(1,53 \%)$ \\
\hline 18 & Thânn Mối & $2(0,82 \%)$ & $3(0,89 @)$ & $2(1,53 \%)$ & $2(1,53 \%)$ \\
\hline 19 & Thần Mặt trời & $2(0,82 \%)$ & $2(0,59 \%)$ & $2(1,53 \%)$ & $2(1,53 \%)$ \\
\hline 20 & Thần Sấm & $2(0,82 \%)$ & $2(0,59 \%)$ & $2(1,53 \%)$ & $2(1,53 \%)$ \\
\hline 21 & Thần Nam Tào - Bắc Đẩu & $2(0,82 \%)$ & $1(0,3 \%)$ & $1(0,77 \%)$ & $1(0,77 \%)$ \\
\hline 22 & Vua Lửa & $1(0,41 \%)$ & $4(1,19 \%)$ & $1(0,77 \%)$ & $1(0,77 \%)$ \\
\hline 23 & Thần báo mộng & $1(0,41 \%)$ & $3(0,89 \%)$ & $1(0,77 \%)$ & $1(0,77 \%)$ \\
\hline 24 & Thần Thiện & $1(0,41 \%)$ & $3(0,89 \%)$ & $1(0,77 \%)$ & $1(0,77 \%)$ \\
\hline 25 & Thần Hang & $1(0,41 \%)$ & $3(3,89 \%)$ & $1(0,77 \%)$ & $1(0,77 \%)$ \\
\hline 26 & Thần ngôi đền & $1(0,41 \%)$ & $2(0,59 \%)$ & $1(0,77 \%)$ & $1(0,77 \%)$ \\
\hline 27 & Thần Parin (lốt thú) & $1(0,41 \%)$ & $2(0,59 \%)$ & $1(0,77 \%)$ & $1(0,77 \%)$ \\
\hline 28 & Thân Biển & $1(0,41 \%)$ & $2(0,59 \%)$ & $2(1,53 \%)$ & $2(1,53 \%)$ \\
\hline 29 & Giao thần & $1(0,41 \%)$ & $2(0,59 \%)$ & $1(0,77 \%)$ & $1(0,77 \%)$ \\
\hline 30 & Thần Suối & $1(0,41 \%)$ & $1(0,3 \%)$ & $1(0,77 \%)$ & $1(0,77 \%)$ \\
\hline 31 & Thần Gió & $1(0,41 \%)$ & $1(0,3 \%)$ & $1(0,77 \%)$ & $1(0,77 \%)$ \\
\hline 32 & Thân Rừng & $1(0,41 \%)$ & $1(0,3 \%)$ & $1(0,77 \%)$ & $1(0,77 \%)$ \\
\hline 33 & Thần Ác & $1(0,41 \%)$ & $1(0,3 \%)$ & $1(0,77 \%)$ & $1(0,77 \%)$ \\
\hline 34 & Thần Thuồng luông & $1(0,41 \%)$ & $1(0,3 \%)$ & $1(0,77 \%)$ & $1(0,77 \%)$ \\
\hline 35 & Thân Sóng & $1(0,41 \%)$ & $1(0,3 \%)$ & $1(0,77 \%)$ & $1(0,77 \%)$ \\
\hline 36 & Thần K'lông Bệ & $1(0,41 \%)$ & $1(0,3 \%)$ & $1(0,77 \%)$ & $1(0,77 \%)$ \\
\hline 37 & Thần Me Sơrah & $1(0,41 \%)$ & $1(0,3 \%)$ & $1(0,77 \%)$ & $1(0,77 \%)$ \\
\hline 38 & Thần Chim & $1(0,41 \%)$ & $1(0,3 \%)$ & $1(0,77 \%)$ & $1(0,77 \%)$ \\
\hline 39 & Thân Mưa & $1(0,41 \%)$ & $1(0,3 \%)$ & $1(0,77 \%)$ & $1(0,77 \%)$ \\
\hline 40 & Thân Thành hoàng & $1(0,41 \%)$ & $1(0,3 \%)$ & $1(0,77 \%)$ & $1(0,77 \%)$ \\
\hline \multirow[t]{2}{*}{41} & Thần Chôm & $1(0,41 \%)$ & $1(0,3 \%)$ & $1(0,77 \%)$ & $1(0,77 \%)$ \\
\hline & Tổng (41 loại) & $243(100 \%)$ & $337(100 \%)$ & $130(100 \%)$ & $130(100 \%)$ \\
\hline
\end{tabular}


- Về số lượng và tần số xuất hiện của nhân vật thần: Trong quá trình chúng tôi khảo sát cụ thể thì số lượng 100 truyện đã tăng thành 130 lượt truyện (Bảng 2). Sở dĩ có tình trạng này là do có một số truyện có tới hai, ba loại nhân vật thần cùng xuất hiện trong một truyện. Mỗi nhân vật thần lại ứng với một lượt truyện. Nếu trong truyện nào đó có hai hoặc ba loại nhân vật thần (thần Nước, thần Núi, thần Biển...) thì sẽ ứng với hai hoặc ba lượt truyện khác nhau.

Trong số 243 nhân vật thần của 100 truyện mà chúng tôi khảo sát được, thần là nhân vật chiếm tỷ lệ cao nhất: 140/243 nhân vật, chiếm 57,61\%. Đây là loại nhân vật có tần số xuất hiện lớn nhất với: 166/337 lần, chiếm 49,25\%. Nếu như trong thần thoại, thần Khổng lồ là loại nhân vật chiếm số lượng nhiều thứ hai (17,5\%) và có tần số xuất hiện lớn nhất (298 lần) trong các nhân vật thì trong truyện cổ tích, thần Khổng lồ chiếm số lượng và tần số xuất hiện khá khiêm tốn (12 lần). Chiếm tỷ lệ thấp nhất thuộc về thần Chim, thần Mưa, thân Thành hoàng...

Sở dĩ, các vị thần, thần Nước, thần Núi, thần Lúa, thần Sét, thần Đất, thần Sông, sơn thần, thần Cây... xuất hiện với số lượng lớn như vậy là do ảnh hưởng từ tín ngưỡng dân gian, từ hệ thống quan niệm "vạn vật hữu linh” của người xưa. Đây cũng là hệ thống nhân vật gần gũi và gắn bó với cuộc sống sinh hoạt xung quanh của con người hơn so với các thân linh khác. Vai trò khái quát của thần trong truyện cổ tích thần kỳ là "giải quyết xung đột, mâu thuẫn của truyện”.

Thần và thần Nước chiếm tần số xuất hiện nhiều nhất trong số các nhân vật thần. Điêu này là có căn nguyên của nó. Với các nước nông nghiệp trồng lúa nước như Việt Nam thì nước là yếu tố đầu tiên và quan trọng nhất: nhất nước nhì phân. Nước cần thiết như vậy nhưng cũng là lực lượng tự nhiên hung dữ mà bao đời nay con người đều phải khắc phục, trị thủy. Việc xuất hiện các thân nói chung cũng xuất phát từ quan niệm "vạn vật hữu linh" từ trong thân thoại. Con người quan niệm xung quanh mình đều có thần linh, có sự chứng giám của các thần nên họ đã tưởng tượng và gán cho vạn vật bóng dáng của thân linh.

Cuộc sống của người dân các dân tộc ít người còn gắn bó mật thiết với núi rừng, sông suối. Bất cứ con suối, bãi, bến nào cũng đều có sự hiện hữu của một vị thần và do vị thần Nước đó cai quản.

Giống như nội dung của những tác động, kết quả trong các truyện thần thoại có nhân vật thần, truyện cổ tích thân kỳ cũng có những nội dung, tác động khá phong phú, bao gồm: ước mơ chiến thắng tự nhiên, cầu ước mưa thuận gió hòa, cuộc sống no đủ, công bằng, chiến thắng kẻ thù, mong muốn hôn nhân hạnh phúc v.v..
Trong số 100 truyện có nhân vật thần xuất hiện để thực hiện các mong muốn trên thì nội dung cuộc sống no đủ, công bằng cho con người chiếm tỷ lệ cao nhất: 28/100 truyện, chiếm 28\%; tiếp đó là mơ ước hôn nhân - hạnh phúc: 18/100 truyện, chiếm 18\%; ở vị trí thứ ba là nội dung chiến thắng tự nhiên với: 12/100 truyện, chiếm $12 \%$; tiếp đó lần lượt là các nội dung về chiến thắng kẻ thù: $10 / 100$ truyện, chiếm $10 \%$; vượt qua thử thách: $9 / 100$ truyện, chiếm $9 \%$; ước mơ công danh: 6/100 truyện, chiếm 6\%; sở hữu phương tiện thân kỳ: 4/100 truyện, chiếm $4 \%$; thay đổi địa vị: $3 / 100$ truyện, chiếm $3 \%$. Có số lượng thấp nhất là nội dung về thay đổi diện mạo với: 1/100 truyện, chiếm $1 \%$. Như vậy, ước mơ về cuộc sống no đủ, công bằng; về hôn nhân - hạnh phúc, chiến thắng tự nhiên...vẫn là những khát vọng mà con người hướng đến trước nhất. Đó là những mong muốn bình dị. Con người thiếu thốn cái gì thì sẽ mong muốn cái đó để sống sung túc, ổn định.

Không phải lúc nào thần cũng trợ giúp con người. Thần nhiều khi còn gây hại cho họ. Có 2/100 truyện, chiếm $2 \%$ là nhân vật thần gây hại cho con người; 7/100 truyện, chiếm 7\% là nhân vật thần cảnh tỉnh con người. Thần đã dùng phép biến hoá để đe doạ hoặc cản trở nhân vật chính thực hiện mục đích của mình. Sau khi gây hại, cản trở con người, nhiều khi thân lại bị chính họ khuất phục, rôi từ đó phải cảm phục, bảo vệ họ (Thần cây đa và người nông dân, Người học trò trung thực, Chàng Gơrăn Dơhông, Cô gái thứ mười v.v...). Đặc điểm chung trong truyện của các dân tộc có thần (thần Sét, thân Cây, thần Miếu) là thường hay thua cuộc con người, bị họ đánh bại và chế ngự. Các vị thần Sét, thần Cây, thần Miếu này cậy mình có những phép màu nên đã rất hách dịch, kiêu căng, tự phụ nhưng rồi cuối cùng lại bị những con người nhỏ bé như người nông dân, người học trò, cô gái v.v... đánh bại. Như vậy, trong quan niệm thẩm mỹ của dân gian, cho dù các vị thần có tài giỏi, phi thường đến đâu nhưng nếu không có những phẩm chất tốt, không lương thiện...thì cuối cùng những cái xấu cũng sẽ bị cái đẹp tiêu diệt và chiến thắng.

- Về giới tính nhân vật thần:

Nhân vật thần là nam giới có số lượng lớn với 228/243 nhân vật, chiếm 93,83\%; nũ giới chiếm tỷ lệ thấp với: 15/243 nhân vật, chiếm 6,17\%. Như vậy, số lượng thân là nam giới chiếm tỷ lệ lớn, khá cách biệt với nhân vật thần là nữ giới. Các nam thần chủ yếu là thần Trời, thần Khổng lồ... vốn là những vị thần mang tầm vóc lớn lao, kỳ vĩ, có sức khỏe vô địch (đặc trưng của phái mạnh). Nữ thần lại là những vị thần vừa khổng lô, mạnh mẽ, vừa mang những nét dịu dàng, nũ tính, cần cù...của phái nữ. Nam thần vẫn là những nhân vật 
chiếm tỷ lệ cao mặc dù những nhân vật nữ thần xuất hiện sớm hơn nam thần.

Sở dĩ, nhân vật là nam giới chiếm số lượng lớn trong truyện cổ tích nói chung có lẽ phụ thuộc vào yếu tố chức năng. Chức năng của nhân vật là nam giới gắn liền với tư duy thân thoại về cuộc chiến đấu của người anh hùng thân thoại xưa. Do sống trong một xã hội nông nghiệp, lại luôn bị ách đô hộ của tầng lớp phong kiến và nạn ngoại xâm, nên người dân Việt Nam thường xuyên đối đâuu với những cuộc đấu tranh lâu dài và gay go để bảo vệ địa bàn cư trú. Trong hoàn cảnh như vậy, nam giới đóng vai trò chủ đạo là điều tất yếu. Hơn nữa, nhân vật là nam giới xuất hiện nhiều trong hệ thống các thần còn là một sự nhấn mạnh bằng tín hiệu nghệ thuật thể hiện quan niệm thẩm mỹ của người xưa. Nam giới xuất hiện nhiêu trong truyện chính là sự đề cao chế độ nam quyền do lễ giáo phong kiến quy định. Những nhân vật này không chỉ là người xây dựng mà họ còn là người bảo vệ bản làng, mang lại cuộc sống ấm no, hạnh phúc cho mọi người, thực hiện mơ ước của con người...Họ cũng là một trong những đối tượng làm thay đổi vận mệnh xã hội, bản thân.

Nhân vật là nữ giới xuất hiện ít hơn nam giới trong truyện có nhân vật thần có lẽ do vai trò của họ chưa được đề cao trong xã hội phong kiến. Thân phận người phụ nữ vẫn còn bị phụ thuộc nhiều vào chế độ thần quyền và lễ giáo phong kiến nghiệt ngã. Khi tôn giáo phát triển (Đạo giáo, Nho giáo), vai trò của nữ giới ít nhiêu bị tác động và dần trở nên mờ nhạt hơn. Như vậy, vai trò của nam thần trong truyện cổ tích thân kỳ các dân tộc ít người có sự thay đổi so với vai trò của nam thần trong thần thoại. Nếu như nam thân trong thần thoại đóng vai trò chính là người kiến tạo vũ trụ sơ khai thì nam thân trong cổ tích thân kỳ lại đóng vai trò chính là người bảo vệ chính nghĩa, trừ ác, diệt gian, bảo vệ bản làng, đem lại cuộc sống ấm no... cho mọi người. Như vậy, vai trò của nam giới trong xã hội thay đổi nên quan niệm thẩm mỹ của dân gian về nam thần cũng thay đổi. Đó cũng là sự thay đổi trong cả diễn trình tư duy nghệ thuật của người xưa.

Nhân vật thần vốn có nguồn gốc sâu xa từ quan niệm "vạn vật hữu linh" mà ảnh hưởng trực tiếp từ thân thoại, khi đi vào truyện cổ tích đã bị thu hẹp dần phạm vi, còn nhân vật người bình dân khẳng định dần vị trí của mình và trở thành nhân vật trung tâm của truyện cổ tích với tư cách là một thể loại phản ánh chủ đề sinh hoạt gia đình và xã hội. Những nhân vật đó không còn mang đậm tính chất thần linh, cũng không có dáng dấp khổng lồ kì vĩ nữa. Họ có diện mạo như những con người bình thường. Họ giảm tính thân linh song lại tăng chất hoang đường, giàu yếu tố kỳ ảo. Đây chính là kiểu phản ánh mang đặc trưng cổ tích. Do đó, con người có thể cùng một lúc sống trong nhiều thế giới kỳ ảo khác nhau như: Thiên phủ, Thuỷ phủ, Âm phủ mà không gặp phải bất cứ trở ngại nào.

Khi xây dựng nhân vật thần trong truyện cổ tích thân kỳ, lòng tin của con người về thân linh và phù phép đã bị sụp đổ song vẫn còn tôn tại ý nghĩa chung về tác động của sức mạnh bên ngoài, quyết định hạnh phúc của nhân vật. Khi tạo nên hình tượng nhân vật thần linh, con người vẫn còn ít nhiều tin vào những lực lượng siêu nhiên, thân bí, nằm ngoài con người và luôn che chở, giúp đỡ họ lúc khó khăn, hoạn nạn. Niềm tin này dẫn đến kết quả là trong hệ thống hình tượng nhân vật kỳ ảo có hình ảnh các thần linh (vì thần linh là nhân vật chính của thần thoại cũng như là tiêu chí quan trọng để phân biệt ranh giới giữa thần thoại và các thể loại tự sự dân gian khác).

- Về thế giới kỳ ảo mà nhân vật thân xuất hiện: Chúng tôi tiến hành thống kê, phân loại 100 truyện cổ tích thân kỳ các dân tộc ít người có nhân vật thân. Tuy nhiên, trong quá trình khảo sát thực tế lại là 117 lượt truyện có thế giới kỳ ảo. Tại sao lại có hiện tượng này? Trong quá trình khảo sát, chúng tôi nhận thấy là: Cùng trong một truyện, có những nhân vật thân chỉ xuất hiện trong một thế giới kỳ ảo duy nhất. Tuy nhiên, cũng có nhiều truyện, nhiều nhân vật thần xuất hiện trong nhiều thế giới kỳ ảo khác nhau hoặc một nhân vật thần xuất hiện trong nhiều thế giới kỳ ảo khác nhau. Điều này tạo nên số lượt thế giới kỳ ảo tăng lên là 117 mặc dù số truyện là 100 . Ngoài thế giới Trân gian, Thiên phủ, Âm phủ, nhân vật kỳ ảo còn xuất hiện cùng lúc trong các thế giới như: Trần gian - Âm phủ - Thiên phủ - Thủy phủ. Như vậy, giống như thần thoại, thế giới kỳ ảo mà nhân vật thân xuất hiện trong truyện cổ tích cũng có sự gia tăng về số lượt xuất hiện. Điều khác nhau duy nhất là nếu như trong thân thoại có sự xuất hiện của thế giới kỳ ảo hỗn hợp thì trong truyện cổ tích lại hầu như không có sự xuất hiện của thế giới kỳ ảo hỗn hợp. Từng loại thế giới kỳ ảo xuất hiện riêng rẽ, độc lập. Điều này có lẽ phụ thuộc vào thế giới quan, quan niệm nghệ thuật của người xưa về thế giới, vũ trụ.

Trong quan niệm của người xưa, thế giới có mô hình "ba tầng, bốn thế giới": Thế giới trên cao, thế giới trên mặt đất (bao gồm cả những thế giới khác cũng tồn tại trên mặt đất) và thế giới dưới mặt đất (âm ty, địa phủ và thế giới thủy cung)... Dù ở dạng thân linh hay dạng người thì thần cũng luôn tồn tại trong một dạng thức linh thiêng, oai vệ.

Ngay từ xa xưa, người Việt cổ đã có một hệ thống quan niệm về vũ trụ, thế giới buổi đầu khá phong phú. "Hình tượng thần thánh trong thần thoại chính là sự sáng tạo nghệ thuật vô ý thức phản ánh một cách chân thực nhận thức thế giới của người xưa. Thông qua 
hàng loạt những nhân vật thần thánh, ta có thể hiểu được quan niệm thực tế và quan niệm thẩm mỹ của con người" 4 .

Quan niệm về vũ trụ của người xưa cũng thật đặc biệt. Họ tin rằng vũ trụ có ba tầng. Trên có trời (Thiên đình), dưới có đất (Âm phủ), giữa có con người (Trần gian). Trước đây, những tầng vũ trụ đó thông tỏ được với nhau bởi các vị điều khiển cả ba thế giới đều ở thiên đình. Chính vì có ba tâng vũ trụ nên các thần và cả người trần nữa có thể đi đến các thế giới khác một cách dễ dàng hơn.

Người xưa cũng quan niệm thế giới Trân gian lại thường được nối với âm phủ bằng một con đường khe núi, một cái giếng không đáy. Dòng nước chính là để người chết gột rửa, rũ bỏ, quên hẳn quá khứ của mình trước khi bước vào thế giới khác, hồi sinh trong thế giới khác.

Mêlêtinxki khẳng định: "Cách phân chia tam giới như vậy là kết quả của cặp đối lập cặp đôi trên/dưới, tiếp đó là kết quả của những đặc tính khác biệt giữa âm giới như là nơi trú ngụ của ma quỷ và thượng giới như là nơi sinh sống của các vị thần và sau đó là những người được tuyển chọn sau khi chết" 5 .

S.Thompson trong cuốn: The Folktale (Truyện cổ tích), xuất bản ở Hoa Kỳ, 1946 cũng đã nhận xét về các mô hình thế giới này như sau: “...trong phân lớn các truyện cổ tích châu Âu, ta thấy có một niềm tin về sự tồn tại của ba thế giới: "trái đất, nơi chúng ta đang sống một cách bình thường; thế giới ở trên cao, hay thiên đường nơi những điêu huyên bí có thể xảy ra; và cuối cùng là thế giới ở dưới thấp".

Có thể thấy, mô hình thế giới ba tâng trong truyện cổ tích là cơ sở vô cùng quan trọng để từ đó khẳng định những ý niệm thống nhất của người xưa về phạm trù không gian, về thế giới. Nó đồng thời còn là sự thể hiện những thủ pháp nghệ thuật mang tính chất nguyên tắc trong truyện cổ.

Trong các thế giới kỳ ảo mà nhân vật thần xuất hiện, Trân gian là thế giới mà thần xuất hiện nhiêu nhất là: 73/117 truyện, chiếm 62,4\%; tiếp đó là thế giới Thiên phủ với: 24/117 truyện, chiếm 20,5\%; thế giới Thủy phủ với 15/117 truyện, chiếm 12,8\%. Chiếm tỷ lệ thấp nhất là thế giới Âm phủ với: $5 / 117$ truyện, chiếm $4,3 \%$. Tỷ lệ xuất hiện ở các thế giới của nhân vật thần trong cổ tích thần kỳ các dân tộc ít người khác với thân thoại. Trong truyện cổ tích thần kỳ, Trần gian là nơi nhân vật thần xuất hiện nhiều nhất để phù trợ cho con người, còn trong thân thoại, nhân vật thần xuất hiện nhiều trong thế giới hỗn mang để thực hiện nhiệm vụ xây dựng và kiến tạo vũ trụ.

- Về không gian kỳ ảo mà nhân vật thần xuất hiện: Trong số 100 truyện, có 35/100 truyện, chiếm 35\% có không gian kỳ ảo, rộng lớn, không xác định; 65/100 truyện, chiếm $65 \%$ có không gian kỳ ảo cụ thể, xác định. Không gian cụ thể, xác định là không gian quen thuộc của cổ tích thân kỳ và gắn với Trần gian nơi con người sinh sống. Không gian này cũng gắn liền với thế giới trần gian là nơi mà nhân vật thần xuất hiện. Như vậy, thân không chỉ sống ở những nơi uy nghiêm mà còn xuất hiện những nơi bình dị như bến nước, con suối nhỏ, bìa rừng v.v...

- Về thời gian kỳ ảo mà nhân vật thần xuất hiện: Trong số 100 truyện, có $61 / 100$ truyện, chiếm $61 \%$ nhân vật thần xuất hiện vào thời điểm ban ngày; 32/100 truyện, chiếm $32 \%$ nhân vật thần xuất hiện vào thời điểm ban đêm; 7/100 truyện, chiếm 7\% nhân vật thần xuất hiện vào cả thời điểm ban ngày và ban đêm. Thần xuất hiện nhiều vào thời điểm ban ngày là để thực hiện chức năng trợ giúp hoặc cản trở, thử thách nhân vật chính hành động. Thần xuất hiện nhiều vào ban đêm là báo mộng cho con người hoàn thành những thử thách, vượt qua khó khăn theo chỉ dẫn của thần.

\section{MộT SỐ NHẬN XÉT, ĐÁNH GIÁ SỰ BIẾN ĐỔI CỦA NHÂN VÂTT THẦN TỪ THẦN THOẠI CÁC DÂN TỘC ÍT NGƯờI ĐẾN CỔ TÍCH THẦN KỲ CÁC DÂN TộC ÍT NGƯờI VIÊTT NAM THÔNG QUA CÁC KẾT QUẢ KHẢO SÁT}

- Nguồn gốc hình thành nhân vật thân:

Từ rất xa xưa, sớm hơn cả thân thoại, thần đã được hình thành từ trong tín ngưỡng dân gian, từ hệ thống quan niệm "vạn vật hữu linh", quan niệm về linh hồn sau khi chết...Tuy nhiên, thần thoại lại có ảnh hưởng trực tiếp đến hệ thống quan niệm này nên những nhân vật thần đó mang đậm dấu ấn của thần thoại.

Những biến đổi xã hội, lịch sử kéo theo sự biến đổi của tư duy con người. Điều này được thể hiện rõ nét trong một số thể loại tự sự dân gian. Từ thần thoại đến truyện cổ tích thân kỳ các dân tộc ít người cũng đã có sự biến đổi như vậy. Hình tượng nhân vật thần từ thân thoại đến cổ tích thân kỳ các dân tộc ít người đã có sự biến chuyển rất nhiều và đa dạng.

Thân có nguôn gốc từ thần thoại mà thần thoại lại có nguồn gốc từ quan niệm "vạn vật hữu linh", từ con người đối diện, đối thoại với tự nhiên...Xét về bản chất, thân xuất hiện từ rất sớm, từ tín ngưỡng dân gian bản địa nhưng lại có ảnh hưởng trực tiếp từ thân thoại.

Có nhiều nguồn gốc hình thành nên nhân vật thần nhưng chúng tôi chỉ nêu ra hai nguồn gốc có mối liên hệ mật thiết đến nhân vật thân là: Nguồn gốc thần thoại, nguồn gốc tôn giáo. 
Thần thoại là sự kết tinh và nghệ thuật hóa những quan niệm cổ xưa về thế giới và sự tôn sùng tự nhiên. “Từ niềm tin vào thế giới tự nhiên thân thánh đó mà người ta sáng tạo thần thoại và thực hành tín ngưỡng nguyên thủy. Người ta diễn xướng thần thoại về các thân trong nghi lễ thờ cúng, tế lễ thần và ngược lại, khi tế lễ các thần không thể thiếu được việc kể lại các chuyện về thần qua hành động hội hoặc ngôn ngữ diễn kể trực tiếp" 4 .

Truyện cổ tích thần kỳ nói chung và truyện cổ tích các dân tộc ít người nói riêng ra đời vào cuối giai đoạn công xã nguyên thuỷ và chủ yếu tôn tại, phát triển trong thời kỳ phong kiến nên niềm tin của con người vào các sức mạnh của tự nhiên vẫn còn. Có thể nói, con đường hình thành của truyện cổ tích thần kỳ từ truyện kể thực dụng mang tính chất thần thoại, nghĩa là từ cái cấu trúc cổ xưa nhất của nó đến hình thức thể loại cổ điển đã được nhiều nhà nghiên cứu phương Tây đề cập đến một cách hợp lý. Tính hợp lý của sự phát triển ấy đã dẫn đến việc khôi phục lại được những bước hình thành liên tục của truyện cổ tích với tư cách là một thể loại.

Trong một công trình nghiên cứu khác, chúng tôi có đề cập đến nguôn gốc hình thành các nhân vật kỳ ảo. Các nhân vật này xuất hiện là do ảnh hưởng từ tín ngưỡng bản địa, tôn giáo v.v...Do chịu sự chi phối trực tiếp của các yếu tố lịch sử và tương ứng với quá trình phát triển lịch sử trong từng giai đoạn của các dân tộc mà mô hình phát triển các nhân vật kỳ ảo, trong đó có thần được sắp xếp theo tiến trình của truyện dân gian Việt Nam (cũng là theo diễn trình tư duy nghệ thuật của người xưa) như sau: Thân linh ra đời sớm nhất dựa trên cơ sở thần thánh hóa tự nhiên; tiếp đó là ma quỷ (quan niệm "vạn vật hữu linh", vũ trụ ba tâng bốn thế giới); tiếp đó là Phật - Bụt xuất hiện khi Phật giáo ra đời; phù thủy, Tiên xuất hiện khi Đạo giáo ra đời (Đạo giáo phù thủy, Đạo giáo thần tiên).

Như vậy, nhân vật thần xuất hiện sớm nhất, tiếp đó mới là ma quỷ, Tiên, Phật - Bụt.. Việc phát triển từ nhân vật thân trong thân thoại đến cổ tích thân kỳ trong lịch sử là một quá trình "con người hóa” các nhân vật. Nhân vật của thần thoại phân lớn là thần, các loại thần linh, những đấng siêu nhiên. Thế giới của họ là vũ trụ bao la. Sức mạnh của thân là sản phẩm của thời kỳ nguyên thuỷ, mang sức mạnh vô địch, vạn năng nên không cần đến sự trợ giúp.

Với truyền thuyết, nhân vật chính là những người anh hùng có công trong việc mở mang bờ cõi, khai sáng văn hóa, chống giặc ngoại xâm nên khả năng thần kỳ nằm ngay trong bản thân nhân vật (nhân vật bán thân), sự trợ giúp tuy có cần thiết nhưng không nhiều.
Đến cổ tích, nhân vật chính là những người khốn khổ, bị chà đạp đến kiệt cùng về tinh thần và thể xác. Họ mất dần niềm tin vào sự đổi thay cuộc đời ở trong xã hội thực tại. Con người hướng ước mơ của mình tới một xã hội khác với cõi trần. Để thể hiện được lý tưởng thẩm mỹ của nhân dân: thiện thắng ác và mong muốn những người bất hạnh được có cuộc sống đủ đầy thì sự xuất hiện của nhân vật thần này là cân thiết.

Như vậy, nhân vật thần trong thân thoại và cổ tích thân kỳ các dân tộc ít người Việt Nam đều có nguôn gốc thân thoại. Thân có nguồn gốc từ thân thoại mà thân thoại lại có nguồn gốc từ quan niệm "vạn vật hữu linh", từ con người đối diện, đối thoại với tự nhiên v.v... Xét về bản chất, thần xuất hiện từ rất sớm, từ tín ngưỡng dân gian bản địa nhưng lại có ảnh hưởng trực tiếp từ thân thoại.

Có thể nói, nhân vật thần đã kế thừa những "chất liệu” truyên thống của thân thoại và được người xưa đưa vào phản ánh trong thể loại truyện cổ tích một cách hữu hiệu là thế giới quan thần thoại, hệ thống quan niệm tín ngưỡng vật linh, sùng bái vật tổ; hệ thống nghi lễ; hệ thống giấc mơ và quan trọng nhất là hệ thống các nhân vật (thần linh, các lực lượng siêu nhiên). Thế giới quan ấy được thể hiện một cách trực tiếp hoặc gián tiếp trong các câu chuyện cổ, về cội rễ phát sinh thế giới và các loại nhân vật thần trong các truyện cổ tích thân kỳ.

Từ các phương diện trên, chúng tôi nhận thấy thần là kiểu nhân vật cần được nghiên cưu một cách hệ thống. Nếu thiếu vắng sự hiện diện của nhân vật thần thì sẽ không thể tạo nên những kết cấu chặt chẽ của cổ tích thân kỳ cũng như đem lại sự hấp dẫn ở phương diện nghệ thuật trong thần thoại. Sự xuất hiện của nhân vật thần với những phép màu, sự biến hóa khôn lường v.v...đã giúp thần thoại, đặc biệt là truyện cổ tích thần kỳ giải quyết xung đột (chủ yếu là các xung đột xã hội), giúp thắt nút, mở nút câu chuyện. Nhân vật thần đã tạo nên những tình tiết ly kỳ, những sự kiện hấp dẫn, làm cho những câu chuyện kể thêm phân lung linh, diệu kỳ hơn.

- Đặc điểm và tính chất nhân vật thần:

Khi viết về tính chất của các lực lượng kỳ ảo, nhà nghiên cứu Hoàng Tiến Tựu đã đưa ra nhận xét: "Lực lượng nảy sinh từ nhiều nguồn gốc khác nhau như quan niệm thần linh trong thần thoại, sự tín ngưỡng của nhân dân (...) nhưng đã được nhào nặn lại theo quan niệm và lý tưởng thẩm mỹ của tác giả truyện cổ tích. Vì thế, các lực lượng thân kỳ trong truyện cổ tích không giống với các vị thần trong thần thoại... Lực lượng thần kỳ trong cổ tích không phải là hiện thân của các lực lượng tự nhiên trong thần thoại..., mà ít nhiều đều mang tính xã hội, tính giai cấp" ${ }^{6}$. 
Sự tồn tại của nhân vật dạng thân linh cho thấy dấu ấn của thân thoại trong cổ tích thân kỳ vẫn còn đậm nét. Tuy nhiên, tác giả dân gian đã "cổ tích hoá" các nhân vật ấy, khiến họ trở nên gần gũi đối với đời sống con người. Như vậy, sự dịch chuyển nhân vật mang tính chất biểu tượng và linh thiêng xuất phát từ ý thức của thân linh trong thân thoại đến truyện cổ tích đã mang nhiều sắc thái mới.

Thần xuất hiện hết sức phong phú. Họ thường hiện ra dưới dạng thân linh (thân Miếu, thân Cây, thân Núi, thần Sét, thần Sấm, thần Rừng, thần Đá v.v...) hoặc cũng có thể xuất hiện ở dạng người. Đó là các thổ thân có tài phép đặc biệt (Một cuộc thi tài); thân Miếu (Người học trò trung thực), thần cây đa (Thần cây đa và người nông dân) phân minh, biết đổi oán lấy ân; thần Thành hoàng (Đôi sam) có nhiều bảo bối; đức thánh Khổng lồ (Người thợ đúc và anh học nghể) biến hoá khôn lường để thử thách nhân cách và tài năng của con người.

Dù ở dạng thần linh hay dạng người thì thân cũng luôn tồn tại trong một dạng thức linh thiêng, oai vệ. Các vị thần như thần Sấm, thần Sét, thần Nước...thường hay mang diện mạo hung dũ̃, chứa đựng sức mạnh của tự nhiên nên nhiều khi làm con người khiếp sợ. Cuộc sống của các vị thần đó cũng không yên bình như người ta tưởng. Có những vị thân thiện hay trợ giúp con người nhửng cũng có những vị thần lại gây hại cho họ như thần Parin hay đội lốt thú để bắt người; thân Sét thường đe dọa và mang đến cái chết cho con người v.v...Mặc dù các nhân vật thần có những phép biến hoá cao siêu nhưng cuối cùng họ lại phải chịu thua con người. Bên cạnh hệ thống thân xuất hiện để trợ giúp con người vượt qua khó khăn, thực hiện được mơ ước của mình, còn có những nhân vật gây cản trở, đe doạ cuộc sống của con người. Vì vậy, khi đề cập đến nhân vật thân là đề cập đến hai tuyến: tuyến thiện và tuyến ác. Đây là những nhân vật có nguồn gốc kỳ ảo nhưng cũng có thể là nhân vật không có nguồn gốc kỳ ảo; là những nhân vật bỗng nhiên biến hoá kỳ ảo nhưng đồng thời cũng là những nhân vật chỉ biến hoá trong một số trường hợp nào đó. Nhìn chung, khi nghiên cứu truyện cổ tích thần kỳ Việt Nam, chúng tôi nhận thấy nhân vật thần ở các vùng, miền khác nhau đều mang những đặc điểm như vậy.

Có thể nói, khi trở thành hình tượng quen thuộc trong truyện cổ tích thần kỳ thì thần lại là những nhân vật mang trong mình nguôn sức mạnh phi thường nhưng đã được hiện thực hoá, cũng biết trò chuyện, biết cảm thông với nỗi bất hạnh của con người, biết cảm phục trước ý chí và nghị lực, đạo đức và phẩm chất của họ. Hình tượng thần ở đây không chỉ là sản phẩm của niềm tin, của trí tưởng tượng hoang đường thời nguyên thuỷ nữa mà đã nhiêu phần mang tính chất hiện thực rõ nét. Việc các vị thân, thân Nước, thần Núi, thần Lúa, thần Sét, thần Đất, thần Sông, sơn thần, thần Cây, thần Lúa... xuất hiện với số lượng lớn như vậy là do ảnh hưởng từ tín ngưỡng dân gian, tù̀ hệ thống quan niệm "vạn vật hữu linh" của người xưa. Đây là hệ thống nhân vật thần xuất hiện gần gũi và gắn bó với cuộc sống sinh hoạt xung quanh của con người hơn so với các thân linh khác.

Khi phân loại nguôn gốc thần thoại của nhân vật thân, chúng tôi căn cứ vào quan niệm của người xưa về mô hình thế giới ba tầng: Thế giới trên cao, thế giới trên mặt đất (bao gồm cả những thế giới khác cũng tôn tại trên mặt đất) và thế giới dưới mặt đất (âm ty, địa phủ và thế giới thủy cung)...cũng tương đồng với hệ thống quan niệm vũ trụ ba tầng bốn thế giới của người Mường (tâng cao nhất là thế giới của Mường Trời, là nơi trú ngụ của vua Trời và các phò tá của vua Trời. Tầng ở giữa là Mường Pưa, là thế giới của người sống, tập hợp lại thành các gia đình, thành xóm và thành mường. Tầng thứ ba có hai thế giới là Mường Pưa Tín ở dưới mặt đất và mường Vua Khú ở đáy nước. Thế giới bên dưới mặt đất không phải là âm ty, có lối thông lên thế giới của người trên mặt đất), các quan niệm vê vũ trụ của người Thái, người Tày, người Nùng v.v...Như vậy, từ rất xa xưa, sớm hơn cả thần thoại, thần đã được hình thành từ trong tín ngưỡng dân gian, từ hệ thống quan niệm "vạn vật hữu linh", quan niệm về linh hôn sau khi chết...Tuy nhiên, thân thoại lại có ảnh hưởng trực tiếp đến hệ thống quan niệm này nên những nhân vật thần đó mang đậm dấu ấn của thân thoại.

- Hành động và chức năng:

Hành động và chức năng của thần cũng xoay theo hai trục chính là: trợ giúp, bảo vệ con người, giúp họ vượt qua thử thách, thực hiện ước mơ của mình và gây hại, cản trở họ. Để thực hiện các hành động trợ giúp hoặc thử thách con người, thần cũng có các hành động và đảm nhiệm các chức năng sau: ban tặng, chỉ dẫn, biến hoá, trừng phạt v.v...

Đối với những con người nghèo khổ, bất hạnh, gặp khó khăn nhưng có những phẩm chất đáng quý thì thần thường ban tặng cho họ những phương tiện thần kỳ, những phép màu kỳ diệu (viên ngọc, thanh gươm, cái hũ thần v.v...), chỉ dẫn cho họ cách vượt qua những trở ngại từ thiên nhiên, từ những lực lượng hắc ám khác. Lý do của việc ban tặng xuất phát từ sự cảm thông, từ thái độ yêu mến và cũng từ sự trả ơn cho nhân vật chính. Thần trả ơn cho con người là vì con người đã cứu giúp họ. Vì mến yêu cuộc sống con người nên thần đã đến với cuộc sống nhân gian. Tại đây, họ gặp tai hoạ và được con người cứu giúp. Không chỉ dùng phép biến hoá để trợ giúp con người, 
thần còn có các hành động chỉ dẫn họ cách vượt qua thử thách để đạt được mục đích. Hình thức để chỉ dẫn cũng như các hành động ban tặng của các nhân vật thần cho con người cũng hết sức phong phú.

Điều đó cũng tuỳ thuộc vào mong muốn, mục đích cũng như hoàn cảnh mà con người đang bị thử thách, cần vượt qua. Trong số các nhân vật sứ giả đưa tin, báo tin, các con vật v.v..., phải kể đến hệ thống thần trong thế giới mộng ảo. Nhũ̃ng nhân vật kỳ ảo này cùng với hệ thống lời chỉ dẫn tâm linh đã dẫn dắt các nhân vật chính hành động thông qua giấc ngủ của họ. Đối với những con người tham lam, có thói hư tật xấu, thần thánh cũng dùng phép biến hoá để trừng phạt. Mục đích của sự trừng phạt này là nhằm thức tỉnh, cảnh cáo con người. Đối với tội ác tày trời của họ, thần luôn trừng phạt nghiêm khắc, thậm chí nhân vật chính còn phải trả giá bằng sinh mạng của mình (Con kiến).

Các nhân vật thần cũng xuất hiện đa dạng với những phép biến hóa kỳ ảo khôn lường trong truyện của các dân tộc ít người khác. Đó có thể là thân Sấm, thần Sét, thân Đất của dân tộc Hrê (Cô gái thứ mười), của dân tộc Mạ (K’Đòng và Ka Ròng); thân Núi của dân tộc Tà Ôi (Lét và Le); thần Parin có tám con mắt kỳ quái của dân tộc Ca Dong (Axanh); vua Khổng lồ $\mathrm{Y}$ Ác của dân tộc Mnông (Chàng đánh cá Y Ang); thần hang của dân tộc Giẻ Triêng (Hang thần Kê Reo); nũ thân Đá của dân tộc Khơ Mú (Chàng Chuối tìm vợ) v.v... Như vậy, các vị thần này cũng mang những đặc điểm sinh hoạt và gắn liền với địa bàn sinh sống của các dân tộc ít người Việt Nam.

Do ảnh hưởng của đặc trưng thể loại và nghệ thuật xây dựng nhân vật thần thoại, nhân vật thần xuất hiện trong truyện chủ yếu vẫn là các nam thần, tương tự như những người đàn ông vốn gánh vác các trọng trách lớn trong đời sống kinh tế - xã hội. Vai trò của nam giới thường được đề cao. Không gian, thời gian xuất hiện luôn vô định, kỳ vĩ, mông lung tạo nên sức hấp dẫn riêng biệt.

\section{KẾT LUẦN}

Như vậy, hình tượng thân trong thần thoại các dân tộc ít người vừa lớn lao, vừa phóng khoáng, mạnh mẽ, trở thành những hình tượng nghệ thuật mang vẻ đẹp tuyệt vời mà các thời đại sau không thể bắt chước. Nhân vật thần trong thân thoại có ảnh hưởng sâu rộng và chi phối trực tiếp đến nghệ thuật xây dựng nhân vật của các thể loại khác tiếp sau nó. Truyền thuyết, cổ tích...là những minh chứng tiêu biểu cho nhận định đó. Có thể nói, nhân vật thần đã kế thừa nhũ̃ng "chất liệu” truyền thống của thần thoại và được người xưa đưa vào phản ánh trong thể loại truyền thuyết, truyện cổ tích một cách hữu hiệu là thế giới quan thần thoại, hệ thống quan niệm tín ngưỡng vật linh, sùng bái vật tổ; hệ thống các nghi lễ; hệ thống các giấc mơ và quan trọng nhất là hệ thống các nhân vật (thần linh, các lực lượng siêu nhiên...) và khiến cho chúng có một sức sống trường tôn, hấp dẫn muôn đời. Có thể nói, từ thân thoại đến truyện cổ tích là một quá trình biến đổi và xâm nhập khá dài và tinh tế. Truyện cổ tích đã kế thừa khá nhiều ở thần thoại, từ quan niệm nghệ thuật về thế giới đến phương thức phản ánh thế giới đó. Thần vốn có nguôn gốc từ thần thoại, khi đi vào truyện cổ tích đã bị thu hẹp dần phạm vi, còn nhân vật người bình dân khẳng định dần vị trí của mình và trở thành nhân vật trung tâm của truyện cổ tích với tư cách là một thể loại phản ánh chủ đề sinh hoạt gia đình và xã hội. Một cách tự nhiên, vô ý thức, con người đã vẽ lên một thế giới khác ngoài thế giới mà họ đang sống với ý tưởng thế giới tưởng tượng trong mộng chính là nơi sản sinh, điều khiển hiện thực trần thế. Đằng sau bóng dáng của thần linh là xã hội, là con người nhân gian đích thực vì thực chất, trí tưởng tượng của con người bao giờ cũng được xây dựng trên những yếu tố hiện thực có sẵn. Thế giới thần linh là cuộc sống con người được nâng lên tầm huyền diệu. Sở dĩ có được sự linh ứng giữa con người và thần linh là do thế giới thần linh và con người hoà lẫn vào nhau như sự hoà lẫn của tưởng tượng vào hiện thực, như sự hoà lẫn thiên nhiên và con người. Người xưa tin vào sự tồn tại của thần linh như tin vào sự tôn tại của họ.

\section{TUYÊN BỐ XUNG ĐộT LợI ÍCH}

Tác giả không có bất kỳ xung đột lợi ích nào trong công bố bài báo.

\section{ĐÓNG GÓP CỦA TÁC GIẢ}

Chỉ có duy nhất một mình tác giả thực hiện tất cả các nhiệm vụ: nghiên cứu, khảo sát, điền dã, thống kê tư liệu, đối chiếu, viết bài.

\section{TÀI LIÊU THAM KHẢO}

1. Khánh DG, Diên CX, Nhơn VQ. Văn học dân gian Việt Nam, tái bản lần 8. Nxb Giáo duc. 2004;p. 588-613.

2. Duy ND. Văn hóa tâm linh. Nxb Hà Nội. 1998;p. 95.

3. Chevalier J, Gheerbrant $\mathrm{A}$. Từ điển biểu tượng văn hoá thế giới, Phạm Vĩnh Cư phụ trách nhóm dịch, Nguyễn Xuân Giao, Lưu Huy Khánh, Nguyên Ngọc, Vũ Đình Phòng, Nguyễn Văn Vỹ dịch. Nxb Đà Nẵng và Trường Viết văn Nguyễn Du xuất bản. 1997;

4. Hà NB. Văn học dân gian Việt Nam, in lần thứ hai. Nxb Đại học Sư phạm. 2010;.

5. Meletinxki EM. Nhân vật truyện cổ tích hoang đường - xuất xú của hình tượng, tài liệu đánh máy lưu tại Viện Văn học. 1958;p. 285.

6. Tựu HT. Văn học dân gian - giáo trình đào tạo giáo viên trung học cơ sở hệ cao đẳng sư phạm. Nxb Giáo dục Hà Nội. 1998;p. 72. 


\section{Some survey results about the change ofgods in myths to gods in the fairy tales of Vietnamese ethnic minorities}

\section{Nguyen Thi Dung*}

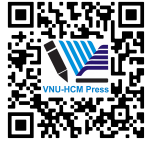

Use your smartphone to scan this QR code and download this article

\begin{abstract}
Gods appear in a wide variety of myths and fairy tales around nations in the world. This is one of the central images, showing a multidimensional awareness of the ancients on the nature and society. Understanding the transformation of the system of god characters in a process of sequences, the system from the myths to the fairy tales of ethnic minorities in Vietnam, we will see the development of awareness levels in thinking, in the spiritual life of the society and of Vietnamese people. From there, we see the development in the thought process and artistic performances of the ancients which were romantic and high-soaring. We also see the similarities and differences in the art of character building in ethnic minorities' myths and legends. The research outcome is to understand the origin the way to reflect the world, the people, the process of changing according to the thought and the art process of the divine character from myth to fairy tales of the Vietnamese ethnic minorities through the following steps: 1) Describing and surveying the divine characters in 181 myths of ethnic minorities in Vietnam; 2) Describing and surveying god characters in 150 fairy tales of typical Vietnamese ethnic minorities; and 3) Giving comment, evaluating the transformation of mythical characters from myths to fairy tales through the survey results.

Keywords: God, myths, fairy tales, change, Vietnam
\end{abstract}

University of Labour and social affairs, $\mathrm{Ha} \mathrm{Noi}$

\section{Corresponding to}

Nguyen Thi Dung, University of Labour and social affairs, $\mathrm{Ha} \mathrm{Noi}$

Email: dungcamg@yahoo.com

History

- Received: 20/2/2020

- Accepted: 30/11/2020

- Published: 20/12/2020

DOI : $10.32508 /$ stdjssh.v4i4.601

\section{Check for updates}

\section{Copyright}

(๑) VNU-HCM Press. This is an openaccess article distributed under the terms of the Creative Commons Attribution 4.0 International license.

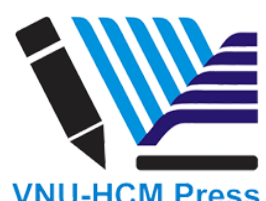

Cite this article as: Dung NT. Some survey results about the change ofgods in myths to gods in the fairy tales of Vietnamese ethnic minorities. Sci. Tech. Dev. J. - Soc. Sci. Hum.; 4(4):549-566. 